\title{
Purchasing Organization and Design: A Literature Review
}

Christoph H. Glock, Assistant Professor of Industrial Management, Julius-Maximilians-Universität Würzburg, Würzburg, E-mail: christoph.glock@uni-wuerzburg.de Simon Hochrein, Department of Industrial Management, Julius-Maximilians-Universität Würzburg, Würzburg,

E-mail: simon.hochrein@uni-wuerzburg.de

\begin{abstract}
This paper presents the results of a comprehensive literature review of the organization of purchasing covering the period from 1967 to 2009. The review provides a structured overview of prior research topics and findings and identifies gaps in the existing literature that may be addressed in future research. The intention of the review is to a) synthesize prior research, b) provide researchers with a structural framework on which future research on the organization of purchasing may be oriented, and c) suggest promising areas for future research.
\end{abstract}

JEL-Classification: M19, L22

Keywords: purchasing, supply, procurement, organization, institutional structure, structure, institution, design, performance, literature review

Manuscript received January 17, 2011, accepted by Peter Walgenbach (Management) August 28, 2011.

\section{Introduction}

Research on purchasing organization (PO) has received increased attention in recent years. 'Strategic purchasing' may be defined as the process of planning, implementing, evaluating, and controlling strategic and operative purchasing decisions for directing all activities of the purchasing function towards opportunities consistent with the firm's capabilities to achieve its long-term goals (Carr and Smeltzer 1997; Ellram and Carr 1994; Zheng, Knight, Harland, and James 2007). The term 'organizational design' refers to the process of assessing and selecting the structure of an organization, which includes formal systems of communication, coordination, control, division of labor, authority and responsibility, with the intention to facilitate the achievement of organizational goals (Robbins 1990: 6-7; Trent 2004). By assigning tasks to the members of an organization and by allocating resources to organizational entities, the structure of an organization is one of the main prerequisites for efficient task completion (Milgrom and Roberts 1992: 25-28; Picot, Dietl, and Frank 2002: 5-9). In an environment characterized by global competition and increasingly demanding customers, a structure that matches the requirements of competition is an essential component of organizational competitiveness.

In the area of purchasing, researchers have studied patterns in the organization of purchasing, identified contextual factors that influence its design or analyzed the contribution of the PO to purchasing performance (PP) or the performance of the entire organization. Although a large number of works have appeared that study the organization of purchasing, several authors noted that prior research has been widely unstructured and that a more systematic approach towards research on the PO is necessary (Trent and Monczka 2003; Gelderman and Semeijn 2006; Quintens, Pauwels, and Matthyssens 2006a; Trautmann, Turkulainen, Hartmann, and Bals 2009).

This paper presents the results of an extensive literature review of the organization of purchasing covering the period from 1967 to 2009. The review provides a structured overview of prior research 
topics and findings and identifies gaps in the existing literature that may be addressed in future research. The intention of the review is to a) synthesize prior research, b) uncover the boundaries of PO research to date and provide researchers with a structural framework along which future research on the PO may be oriented, and c) identify gaps in the study of the $\mathrm{PO}$ and suggest promising areas for future research.

The remainder of the paper is structured as follows: The next section discusses the methodology of the literature review and the research design and proposes a classification and descriptive analysis of literature on the organization of purchasing. Subsequently, a thematic analysis of prior research is presented. The last section discusses the findings of this review, clarifies its limitations and provides suggestions for future research.

\section{The literature review approach}

\subsection{Methodology}

To identify articles of high scientific value and sustainable influence on the academic discussion in purchasing research, a comprehensive literature review was conducted by the authors in 2010. Synthesizing existing evidence in a systematic and transparent way is an effective tool in the building of knowledge, and can be as important as conducting new research (Light and Pillemer 1984: 2-3; Cooper 2010: 1-2). The methodology used in the literature review was developed with reference to the works of Reynolds, Simintiras, and Vlachou (2003); David and Han (2004) and Newbert (2007) and consists of three steps:

(1) The selection of journals is based on the suggestions by Quintens, Pauwels, and Matthyssens (2006a); Pagano (2009) and Walker (2009), who provided literature reviews in the context of purchasing. Thus, a journal list was generated by selecting the most relevant journals in the disciplines general management, international business, international marketing management, and operations and supply (chain) management. The most relevant journals in the respective disciplines were selected by referring to the papers by Quintens, Pauwels, and Matthyssens (2006a); Pagano (2009) and Dubois and Reeb (2000) for international business, Hult, Neese, and Bashaw (1997); Quintens, Pauwels, and Matthyssens (2006a) and Pagano (2009) for mar- keting, Peng (2001); Pagano (2009) and Walker (2009) for general management, and Quintens, Pauwels, and Matthyssens (2006a); Pagano (2009) and Walker (2009) for operations and supply (chain) management. Through this approach, 42 journals were selected in total.

(2) After the journal list had been completed, keywords were defined to facilitate the selection of relevant articles. With reference to the reviews mentioned above, three groups of keywords were defined. Group A contained 'sourcing', 'purchasing', 'procurement', 'supply', 'buying group' and 'buying center', group B 'organization', 'design', 'centralization', 'decentralization', 'team', 'structure', 'size', 'formalization' and 'specialization', and group C 'purchasing partnership', 'commodity teams', 'international purchasing office', 'international procurement office', 'lead buyer' and 'contingency theory', both in British and American spelling.

(3) The paper selection process was initiated by a manual review of all 42 pre-selected journals. In the first step, the titles of all papers that appeared in these journals were checked in light of the keywords defined above (also Walker 2009; David and Han 2004; Newbert 2007). Thereby, articles were checked for relevance of whether they contained a keyword from both groups A and B or from group C in the title. Thus, 226 articles could be identified that met these search criteria. These papers were subjected to a further analysis of their abstract and, in case they seemed to be relevant for this literature review, selected and completely read to examine their content (Pagano 2009). In total, 45 papers were identified as relevant in this step.

In a second step, the online databases Business Source Premier and ABI/Inform Global were searched using the keywords defined above. The intention was to identify additional works that appeared in journals that were not pre-selected and to assure that no important papers were overlooked in the first step of the selection process. Thereby, articles were checked for relevance of whether they contained a keyword from both groups A and B or from group $\mathrm{C}$ in the title and abstract, which led to 473 articles that could be found with Business Source Premier and 428 articles that resulted from the search with ABI/Inform Global. Again, papers that met the search criteria were subjected to an analysis of their abstract and, in case they seemed to be relevant and had not already been selected before, were included in the sample. In total, five addi- 
tional papers could be found in this step of the search phase. In selecting the papers, we focused only on works that appeared in peer-reviewed journals to ensure that only high-quality research was considered in the review. As Light and Pillemer (1984: 35) noted: 'Restricting a review to published studies may enhance quality control. Most refereed journals have reasonably strict requirements for publication [...] This process usually leads to a better technical product.' Works that appeared in peerreviewed, non-business management journals (for example, with a focus on healthcare) were also excluded.

In a third step we consolidated our results. As the review needs to be focused, we excluded works that concentrated on behavioral and informal aspects in POs or that interpreted the organization of purchasing from a process-oriented, and not from a hierarchical perspective. In addition, we excluded papers that studied supply chain management and logistic organization issues.

In a final step, papers were identified in a 'snowball approach' by checking articles that were cited in previously selected works and where the citation indicated that the paper might be relevant for this review. In this way, 35 additional articles were identified. Appendix A gives an overview of selection filters and criteria as well as the number of articles returned at each step of the selection process. In addition, we included the hits of the keyword search for 'title', 'abstract' and 'title and abstract' for information purposes.

In total, 85 papers were identified as relevant in the selection process. The process considered all volumes of the pre-selected journals and all volumes available in the online databases (Business Source Premier since 1965; ABI/Inform Global since 1971) due to the lack of a comprehensive literature review in this area and the need to cover both the state of the art of research on the PO as well as its emergence. Although searches were conducted for the period before 1967 due to the coverage of the databases and the availability of journal volumes, the earliest relevant paper was published in 1967, which leads to a period of analysis covering the years from 1967 to 2009. Identified articles were finally read completely before subjecting them to descriptive and thematic analysis. The bibliographic information was coded and the selected papers were classified with reference to the content categories of the analytical framework of this review (explained below in more detail). Appendix B gives an overview of reviewed journals and the number of identified articles.

\subsection{Analytical Framework}

The following section develops a conceptual framework which illustrates the environment-structureperformance relationship in purchasing. The framework will be used for guiding the content analysis of the review and aims at giving the analysis a structure, which can be reproduced by the reader and which helps researchers to better position their own work in the literature on POs. The content analysis, in turn, aims at giving an objective, systematic, and qualitative description of research content (Reynolds, Simintiras, and Vlachou 2003). A clear definition of categories and framework components helps to ensure reliability when conducting a content analysis and facilitates classification and consistent assessments. The content categories were derived with the help of Holsti's (1969: 3-23, 94-95) principles, who stated that content categories should be (1) guided by theory, (2) exhaustive to cover all appropriate items in the sample and reflect all issues addressed by the review, (3) mutually exclusive to ensure that a content item is classified under one category only, and 4) independent (to analyze).

The framework is based on works from the purchasing (Stanley 1993), marketing (Ruekert, Walker, and Roering 1985) and organization (Donaldson 1987) literature and will be used as an outline for structuring the thematic analysis in the following sections. According to Ruekert, Walker, and Roering (1985), an environment-structure-performance framework: (1) concretizes the design options by discussing the structural variables,

(2) identifies the contextual factors moderating the effects of structure on performance,

(3) recognizes the diversity of organizational structures available for implementing purchasing activities, and

(4) examines the likely impacts of organizational structure on performance.

To analyze the determinants and structural characteristics of POs and to assess the performance of alternative structural designs, the contingency and the configuration approach can be used (Meyer, Tsui, and Hinings 1993). Both theories study the relationship between the environment of an organization and its structure (Child 1970; Stanley 1993) 
and build on Mintzberg's (1980) discussion of different organizational forms. As contingency theory proposes that institutions with different organizational designs perform better when their structure is properly aligned with the conditions of the environment, organizational decisions in purchasing have to take account of performance dimensions (Child 1972). The idea that the structure of an organization determines its performance is described by the system-structural view of organizational design and performance (e.g., Stanley 1993; ZeyFerrell 1981; Ruekert, Walker, and Roering 1985). Performance can be conceptualized as a multidimensional construct integrating the dimension efficiency, effectiveness and adaptiveness (Stanley 1993; Ruekert, Walker, and Roering 1985):

(1) Efficiency is defined as the relationship between organizational output and the inputs needed to attain those outputs.

(2) Effectiveness measures the degree to which organizational goals are reached and is achieved by fitting characteristics of the organization to its context (Lawrence and Lorsch 1967; Child 1975; Donaldson 2001: 1)

(3) Adaptiveness refers to the ability of an organization to react to changes in its environment.

For the sake of brevity, we exclude measures a company may take to influence the environment from the analysis, although it is clear that the 'strategic choice' typically includes more than the definition of structural forms (Child 1972). Finally, the main focus of our analysis is on the formal structure of POs, which may directly be influenced by decision makers in the company, and excludes the 'social structure' (Blau 1970), e.g., the informal relations and behaviors of individuals within the buying center, which can only indirectly be influenced by management. However, it is clear that formal structures of organizations try to control the social behavior of its members as well. To describe the structure of organizations, we use findings of the contingency approach which is complemented by further contextual factors identified in the organization literature (Blau 1970, 1972). Configuration theory extends the framework by adding individual design dimensions (Meyer, Tsui, and Hinings 1993).

The conceptual framework used in this paper is shown in Figure 1. In the center of the framework, we locate the structural characteristics of the purchasing function, which represent alternative variables of POs. In reviewing the literature, we identified (de)centralization, formalization, configuration, specialization, involvement and standardization as the most commonly used structural variables in purchasing research (also Pugh, Hickson, Hinings, Macdonald, Turner, and Lupton 1963; Pugh, Hickson, Hinings, and Turner 1968). Works that study structural variables will be reviewed first to identify alternative dimensions of POs and to assess their importance.

The second component of our framework are the determinants of the organizational design of purchasing, which are located to the right and to the left of the structural characteristics in Figure 1. In reviewing the literature, we found that the most frequently used contextual factors in purchasing research can be grouped into factors that are internal to the company, but that are located outside of the PO (such as organization characteristics, product characteristics and the purchase situation) and factors that are company-external (environmental) (also Lewin and Donthu 2005). Figure 1 illustrates that the contextual factors influence the characteristics of the PO and that a fit has to be created between environment and structure to reach a high level of performance. The determinants of the PO will be discussed second.

While the structure of purchasing is frequently interpreted as a response of the organization to its context, the design of purchasing can also be seen as a contextual variable that influences other parts of the organization. Thus, the third part of our analysis will discuss works that studied the purchasing structure as a contextual variable.

The structural characteristics of purchasing shown in the center of our framework constitute a set of dimensions which define a continuum of alternative organizational forms. The literature on purchasing, however, often refers to a discrete set of POs, such as international procurement offices, purchasing teams or the commodity management approach, and does not fully use the continuum provided by the different structural dimensions to characterize POs. As a result, the fourth part of our literature review will give an overview of alternative institutional types of POs that have been discussed in the literature. We thereby differentiate between the POs of private and public institutions, as purchasing in the public sector is subject to a different set of regulations, which may influence the structure of purchasing as well. 
In the last part of our review, we will focus on the purchasing performance impact of organizational design decisions in general and the PO in particular.

\subsection{Descriptive analysis}

In total, 85 papers were identified and assessed (articles are listed in Appendix C). The largest number of papers (44 articles) appeared in operations and supply (chain) management journals, particularly in the Journal of Supply Chain Management (24 articles) and the Journal of Purchasing and Supply Management (14 articles). Further, several marketing journals published research on organizational issues in purchasing (27 articles). International business ( 1 article) and general management journals (2 articles), in contrast, gave limited attention to structural aspects of purchasing. These results confirm those of Quintens, Pauwels, and Matthyssens (2006a) and Pagano (2009) in the field of supply management. In addition, 11 articles were identified that appeared in journals other than the 42 selected. Appendix D gives a detailed overview of the number of relevant articles identified by year and selected journals.

\section{Figure 1: Conceptual Framework}

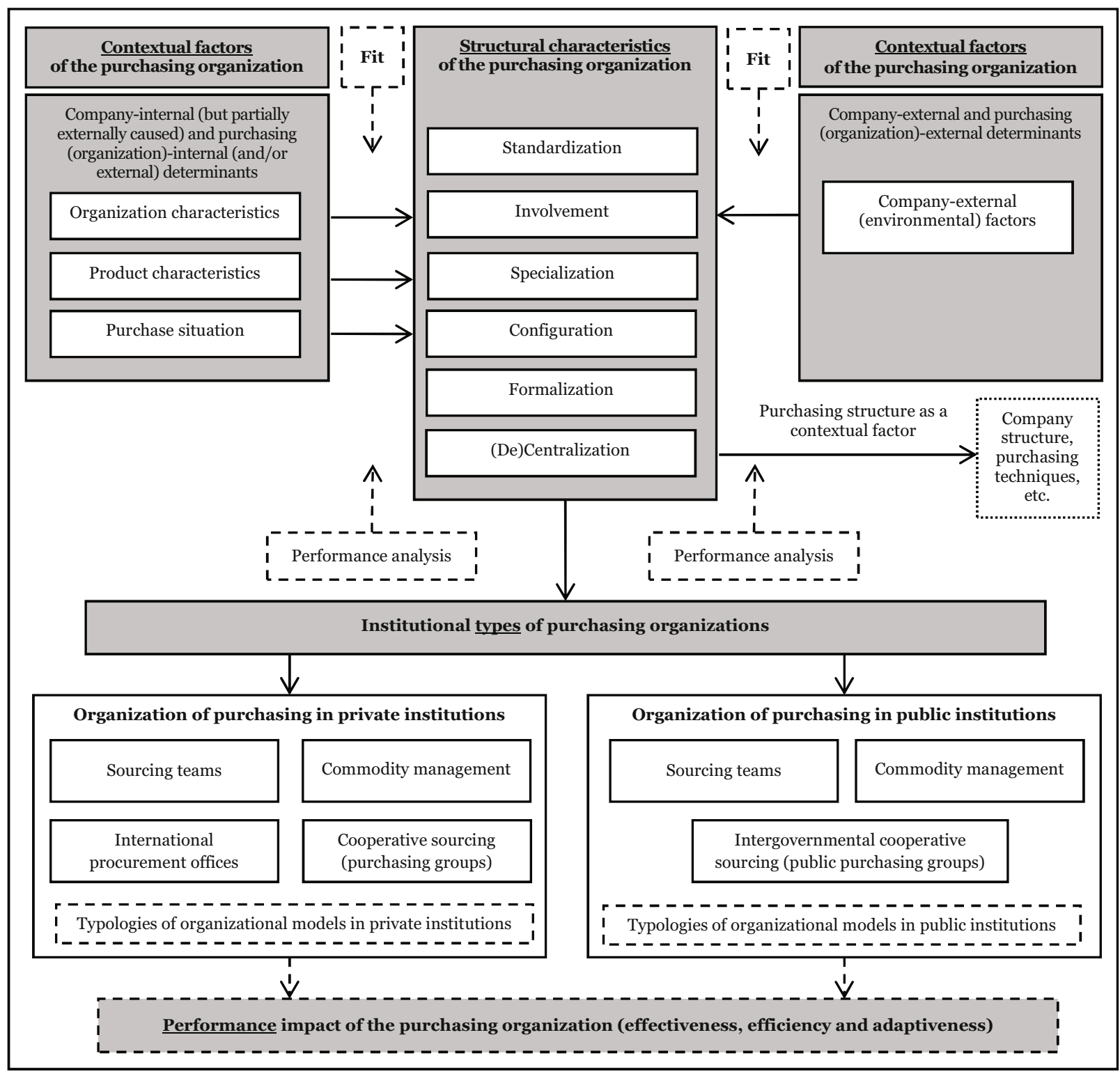


The total number of articles published per year was analyzed as well and the results are shown in Appendix $\mathrm{E}$. The trend line illustrates that research on organizational aspects of purchasing has increased over the years. This result is in line with the objective of this literature review, which is to synthesize findings and to identify research gaps in an area which is becoming more and more important.

As to the main methodological approaches used in the works reviewed in this paper, articles were divided into three categories: A paper was considered to be an empirical survey when the focus was on the collection and analysis of large-scale empirical data. Case studies, in turn, referred to a limited set of organizations and either applied known methods or used real-life examples for theory-building (e.g., Eisenhardt 1989; Yin 2009). Finally, papers were considered to be conceptual if the main focus was on the description of a theory, on methods, algorithms or fundamental discussions. Conceptual papers may use some test data or deal with theoretical or professional issues. It is obvious that a clear distinction between the three categories is not always possible as integrated research methods exist. If surveys or case studies were combined with conceptual considerations, these hybrid papers were assigned to the survey or the case study category, depending on the main focus of the research method used (Appendix H).

Appendix F illustrates that prior works on the organization of purchasing primarily used case study(22) or survey-based (54) approaches and that only a small number of purely conceptual papers exists (9). The use of different methodical approaches by number of articles and year is analyzed in Appendix F. As can be seen, there is a trend shifting research from large-scale empirical studies to case-study research. The increased use of case studies indicates that research is becoming more and more exploratory in nature as this approach is able to provide more in-depth knowledge of organizational issues (similar findings by Pagano 2009 in the context of the organization of international sourcing).

The components of our analytical framework were also analyzed with respect to their use in research over time. Appendix G illustrates that structural variables and institutional structures in purchasing have frequently been the object of research in recent years, but that the study of contextual factors has declined continuously after reaching a peak in the late 1990s. Research on the performance impact of the PO began in the mid-1980s, but has not been researched extensively to date.

Figure 2 gives an overview of different theories that have been used in prior research to explain the structure of the purchasing function. It can be seen that especially contingency theory has been used to study the organization of purchasing and its determinants, but that a variety of other theories have been used as well to explain how POs are structured and why they are organized in a certain way. It becomes apparent that only eight out of 85 papers discussed in this review based their research on an established theory, and only six articles used more than one theoretical construct. Appendix I contains a brief outline of works that used an established theory in analyzing the PO and summarizes their main contribution.

\section{Figure 2: Theories used in research on the organization of purchasing}

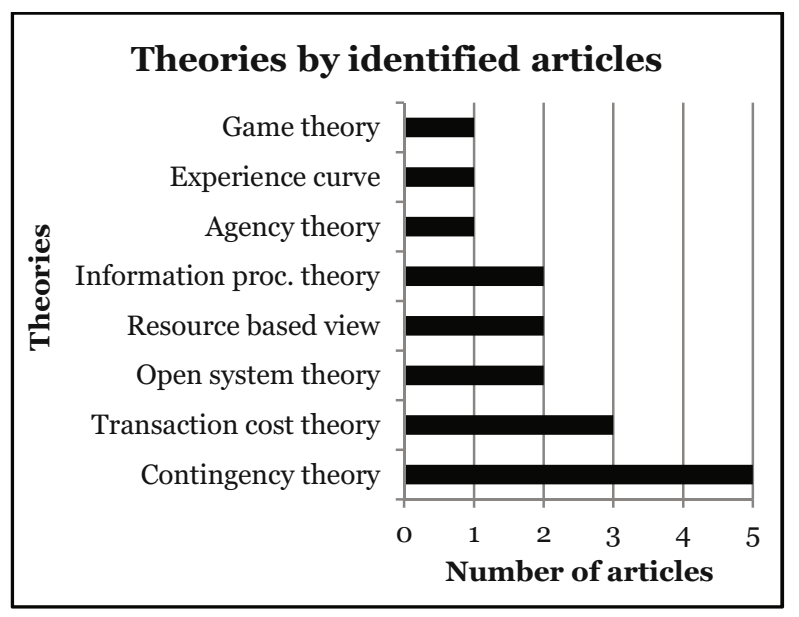

Finally, a journal-specific analysis of the research content did not indicate that certain topics were exclusively or mainly discussed in certain journals or journal categories.

\section{Literature review on the organization of purchasing (thematic analysis)}

\subsection{Structural characteristics of the purchasing organization}

The structure of an organization defines responsibilities and authorities and determines how tasks are allocated to the members of an institution and which resources are available for achieving organi- 
zational goals (Robbins 1990: 4-7; Jones 1998: 1112). In the past decades, researchers have tried to identify important characteristics of organizations and defined structural variables that may be interpreted as basic building blocks of organizations and that help to describe organizations in detail (Pugh, Hickson, Hinings, Macdonald, Turner, and Lupton 1963; Pugh, Hickson, Hinings, and Turner 1968; Price 1972; Mintzberg 1979: 65-213; Robbins 1990). Figure 3 gives an overview of the different structural variables that have been used in prior research to describe the organization of purchasing. The characteristics of the variables and their importance for purchasing research are briefly discussed in the following.

The first structural variable depicted in Figure 3, standardization, refers to the degree to which organizational activities or organizational routines are precisely defined (Garrido-Samaniego and Gutiérrez-Cillán 2004). Quintens, Pauwels, and Matthyssens (2006b) differentiated between process, product and personnel standardization to account for different objects that may be standardized. Standardizing materials reduces the variety of different products that need to be bought and increases the volume for each product type, which typically results in better purchase conditions, while standardizing processes increases the effectiveness and accuracy of the purchasing process (SanchezRodriguez, Hemsworth, Martinez-Lorente, and
Clavel 2006). Further, using standards in purchasing entails that activities can be performed in a routine manner, which reduces variability and helps to lower uncertainty in purchasing. However, as Trautmann, Turkulainen, Hartmann, and Bals (2009) pointed out, standardization limits the organization's capacity to process information, wherefore it should only be used as a design instrument in purchasing in case information processing requirements are not too high.

The second structural variable shown in Figure 3, specialization, refers to the division of labor in the organization (Klebba and Dwyer 1981; GarridoSamaniego and Gutiérrez-Cillán 2004). Several authors differentiated between two forms of specialization and suggested that tasks may either be grouped by functions or by objects (e.g., Germain and Dröge 1998; Robbins 1990: 84-86). The case of a functional segmentation entails that jobs are broken down into simple and repetitive tasks which may be efficiently performed (Robbins 1990: 84; Daft 1992: 13). The case of an object-oriented specialization, in turn, helps to reduce interface problems since employees are responsible for different tasks that are logically interconnected. Consequently, functional specialization in purchasing is beneficial in case only few interdependencies arise between different tasks and high efficiency improvements are expected in specializing on a small set of activities, whereas an object-oriented specialization

Figure 3: Use of structural variables in research on purchasing organizations

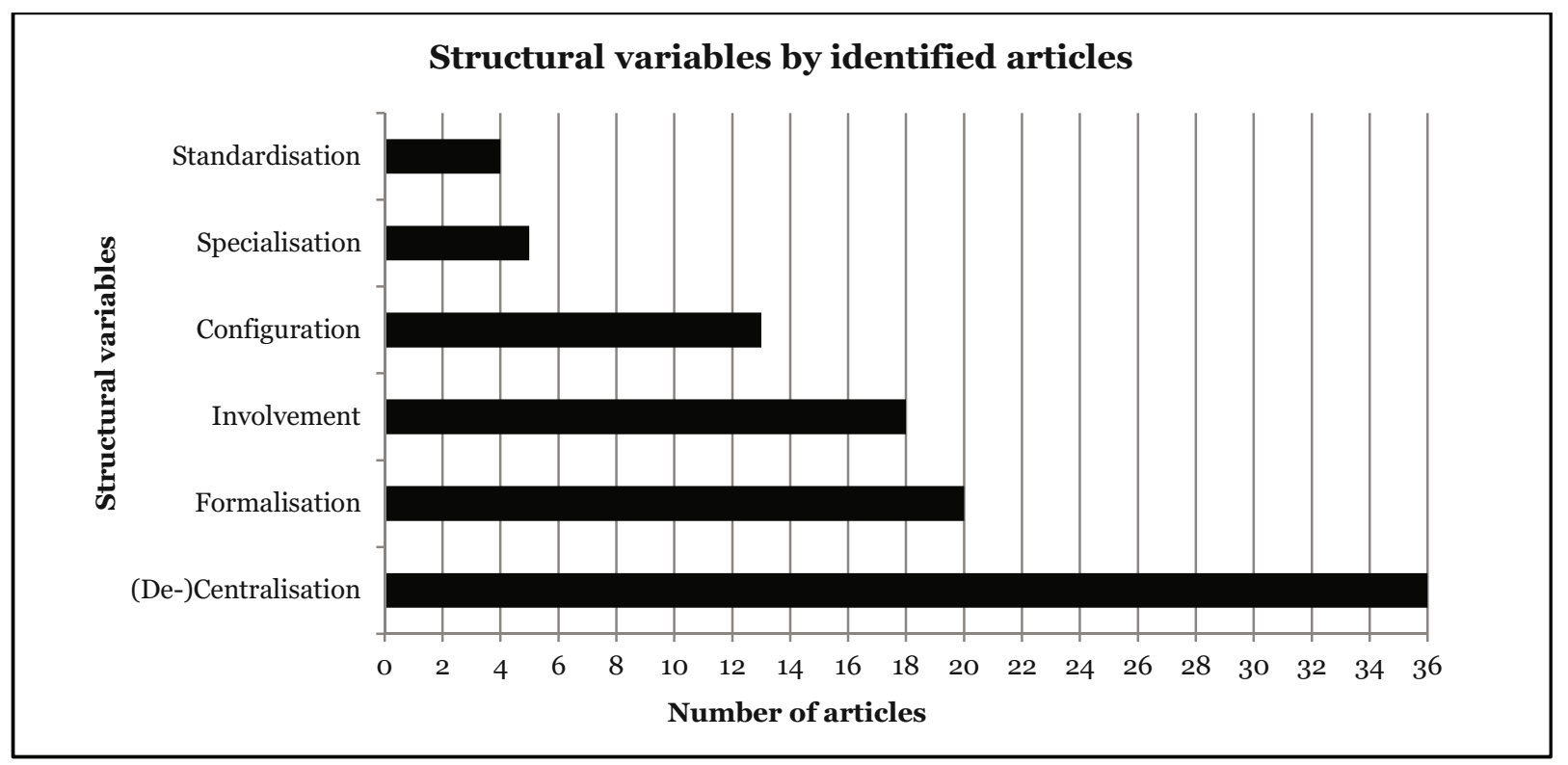


is beneficial in the opposite case (Galbraith 1971; Daft 1992: 191). Spekman and Stern (1979) and Juha and Pentti (2008) further pointed out that specialization is an important measure to reduce risks in the purchasing process, as it enables individuals to react more quickly to changes in the environment. A further discussion of this variable can be found in Lau, Goh, and Phua (1999).

The structural variable configuration refers to the design of the authority structure of the organization and includes dimensions such as vertical and lateral spans of control, criteria for segmentation, and numbers of positions in various segments (Pugh, Hickson, Hinings, Macdonald, Turner, and Lupton 1963; Pugh, Hickson, Hinings, and Turner 1968). A high degree of configuration in purchasing results in a PO that implements a high number of different design elements, such as positions, departments, formal communication channels or control structures, and that may thus better match the requirements of the purchase situation. A closer look at the literature reveals that the variable configuration has not been analyzed per se, but that authors have concentrated on developing concepts for structuring the purchasing function or on studying the use of different design elements in purchasing, which influence the degree of configuration. Narasimhan and Carter (1990); Giunipero and Monczka (1990, 1997); and Cavinato (1992), for example, described different structural alternatives for purchasing, such as product line divisions or geographic area divisions, and defined hierarchical relationships for the purchasing function as well as prerequisites for using the respective structural alternatives.

Another design element that may be summarized under the heading configuration is the hierarchical position of the purchasing department. Many authors agree that the position of an organizational unit helps to assess the status this unit enjoys in the organization and the degree to which an organizational unit may influence decisions on the strategic and tactical level (Bloom and Nardone 1984; Fearon 1988; Monczka, Trent, and Handfield 2002: 66-69). Based on empirical observations, several authors identified a tendency of CPOs reporting more and more to one of the top executive positions (Johnson, Leenders, and Fearon 1998a,b, 2006; Johnson and Leenders 2006), which might indicate an increasing importance purchasing enjoys in the respective companies. In addition, Trent (2004) found that a higher-level procurement officer is critical to organizational design effectiveness.

Finally, also the characteristics of the chief purchasing officer (CPO) are in a broader sense part of the variable configuration. It is clear that $\mathrm{CPO}$ characteristics can be influenced via personnel management in many cases, for example, by hiring or firing employees or by training purchasing agents to develop certain qualifications. In this context, studies of Johnson, Leenders, and Fearon (1998a,b, 2006) and Johnson and Leenders (2006) examined CPO title, education, and responsibilities across a variety of organizations and concluded that the characteristics of the CPO reflect the importance that purchasing enjoys in the respective companies. A comparative analysis of different studies indicated that CPOs became better educated over the years and that simultaneously more responsibilities were transferred to the purchasing function (Johnson, Leenders, and Fearon 1998a, 2006; Johnson and Leenders 2006; Pooley and Dunn 1994). Further, it has been shown by Garrido-Samaniego and Gutiérrez-Cillán (2004) that the experience of an individual involved in the purchase decision is positively related to his or her participation in the decision process. Obviously, an increase in the education or experience of a purchasing agent reduces the need to involve other individuals in the purchasing process. Another aspect that has been analyzed in this context is the centrality of the purchasing manager, which measures the influence of the purchasing manager on the buying decision. This variable has thus far only been analyzed by Johnston and Bonoma (1981a), who were unable to illustrate its impact on the buying decision or its antecedents.

The variable involvement may be subdivided into the variables lateral involvement and vertical involvement and also includes the size or extensivity of the buying center. Lateral involvement measures the number of separate departments, divisions or functional areas participating in the purchase decision, while vertical involvement measures the number of hierarchical levels involved (Johnston and Bonoma 1981a). As the number of departments involved in the purchasing process increases, more information becomes available, which helps to reduce uncertainty. Thus, it may be assumed that the degree of lateral involvement in purchasing increases as the purchase decision becomes more uncertain and risky (Dawes, Dowling, and Patterson 1992). Mattson (1988) further pointed out that an 
increase in the degree of lateral involvement elevates the number of individuals exerting influence on the purchase decision, which typically reduces the influence of the purchasing department on the purchase. In contrast, if individuals on high hierarchical positions act as decision-makers in the purchasing process, information and resources required for the purchase become readily available (Grønhaug 1975, 1976). Consequently, high levels of vertical involvement can often be found in organizations facing complex or uncertain purchase decisions (Johnston and Bonoma 1981a; Mattson 1988; Dawes, Dowling, and Patterson 1992). Laing, Cotton, Joshi, Marnoch, McKee, and Reid (1998) showed that the buying decisions of hospitals is characterized by a high degree of involvement for medical personnel, while Schiele (2005) showed that purchasing managers in public institutions are typically involved in the purchasing process of services in its middle and later stages, i.e. especially in formulating tender documents and in supervising and controlling the purchasing process.

The size or extensivity of the buying center measures the number of people involved in the purchasing process and does not refer to the affiliation of the individuals (Appendix $\mathrm{H}$ for a list of works that study size as a structural variable). Empirical studies indicate that an increase in the size of the buying center leads to higher decision quality in the purchasing process (Johnston and Bonoma 1981a), wherefore increasing the size of the buying center has often been used as a measure to reduce uncertainty or the level of perceived risk in purchasing. Although several studies indicated that the influence of an individual on the purchase decision may decrease with higher levels of extensivity, McCabe (1987) pointed out that an increase in the size of the buying center does not necessarily lead to a diffusion of authority, since decision authority may still be exercised by a small group of individuals.

Finally, also the number of communication channels in the buying center may be interpreted as an indicator of involvement. The more communication channels there are in the buying center, the easier it is for its members to influence the buying decision. Johnston and Bonoma (1981a) analyzed the number of communication channels in the buying center and showed that it is high especially in centralized and little formalized environments.

One of the most frequently used structural variables, formalization, describes the degree to which an organization relies on rules and procedures to direct the behavior of its members (Hickson 1966; Hall, Haas, and Johnson 1967; Pugh, Hickson, Hinings, and Turner 1968; Price 1972: 107-117; Germain and Dröge 1998; Robbins 1990: 93-97). In a highly formalized organization, the job incumbent has a minimum amount of discretion about how the different tasks can be completed. Formalization can be achieved by defining roles and authority relations or by establishing rules that regulate decision processes, the communication of employees, or the processing of information in the organization (Hall, Haas, and Johnson 1967). Organizations formalize the behavior of their members to reduce its variability and to predict and control it (Robbins 1990: 9394), although very high levels of formalization may reduce the motivation of the organization's employees (Hartmann, Trautmann, and Jahns 2008). Formalization has frequently been used as a measure to counter uncertainty or to moderate the characteristics of the purchase situation (Appendix $\mathrm{H}$ for a list of works that study formalization as a structural variable). Besides reducing the variability of employee behavior, formalization contributes to the standardization of work by establishing rules and regulations that ensure that tasks are fulfilled alike by all members of the organization (Hall, Haas, and Johnson 1967; Robbins 1990: 93-130).

The structural variable that has most often been used in purchasing research is the degree of (de-) centralization of the PO. A closer look at the literature reveals that two different definitions are frequently used to measure the degree of (de)centralization. The first definition refers to the concentration of decision-making authority and measures the extent to which authority is aggregated in a single organizational unit (Pugh, Hickson, Hinings, Macdonald, Turner, and Lupton 1963; Price 1972: 43-57; Germain and Dröge 1998; McCue and Pitzer 2000). The position of the organizational unit(s) in the overall hierarchy of the organization is irrelevant in this context, wherefore highly centralized units may also be found on low hierarchical levels. The second definition refers to the position of decision-making authority within the hierarchy of the organization, wherefore only those organizations are considered to be centralized which concentrate authority on high hierarchical levels (Hickson, Pugh, and Pheysey 1969; Jennergren 1981; Robbins 1990: 104-113; Gianakis and Wang 2000; Quintens, Pauwels, and Matthyssens 2006b). The degree of 
(de-)centralization of purchasing has been studied in a variety of works, which can broadly be categorized into three research streams (Appendix $\mathrm{H}$ for a list of works that study (de-)centralization as a structural variable). First, authors have developed concepts for a centralized, decentralized, or hybrid $\mathrm{PO}$ and described criteria for the implementation of the different concepts and their impact on the efficiency of the purchasing process (Corey 1978; Cavinato 1992; Arnold 1999). Obviously, organizations have to weigh the greater flexibility and better service to (internal) customers of decentralized structures against the scale effects of centralized purchasing departments. Second, researchers have studied determinants of (de-)centralization and analyzed which factors, internal or external to the organization, determine whether a centralized or decentralized purchasing organization should be used. Contextual factors of the PO are discussed below. Third, authors have studied the use of centralized, decentralized, and hybrid POs in different industries and tried to interpret changes in the organizational structure of purchasing. The study results indicate that hybrid POs are most commonly used in many industries and that a shift towards a higher use of hybrid POs has occurred over time. Highly centralized POs seem to be more prevalent than highly decentralized structures, especially in the public sector (Fearon and Ayres 1967; Fearon 1988; Giunipero and Monczka 1990, 1997; Johnson, Leenders, and Fearon 1998b, 2006; Johnson, Leenders, and McCue 2003; Johnson and Leenders 2001, 2004, 2006).

Finally, several authors have proposed syntheses of the structural variables introduced above and analyzed them in the context of purchasing. Laios and Xideas (1994a,b); Kotteaku, Laios, and Moschuris (1995) and Xideas and Moschuris (1998), for example, defined depth of analysis as the sophistication of purchasing records and the extent to which technical and financial analytical tools are used in the purchasing process. Further, articulation was defined as the degree to which purchasing activities are conducted by specialized departments, committees and skilled personnel, and the degree to which discrete purchasing tasks are performed in a routine manner. A high degree of depth of analysis leads to a well-documented and transparent purchasing process and makes relevant information available, which helps to reduce uncertainty. Articulation, in turn, includes elements of specialization, lateral and vertical involvement and formalization and consequently helps to structure the purchasing process and reduce its variability. Quintens, Pauwels, and Matthyssens (2006b) finally combined the two structural dimensions (de-)centralization and standardization by introducing the construct global purchasing strategy, which is based on these two variables.

\subsection{Determinants of the purchasing organization}

Besides describing the structural design of organizations, an important task of organization theory is to identify contextual variables and to explain their impact on the structure of organizations. In this context, contingency theory assumes that the structure of an organization is shaped by factors internal and external to the organization, and that creating a fit between the structure and the environment leads to efficiency (Lawrence and Lorsch 1967; Ford and Slocum 1977).

In the last decades, a variety of different contextual variables has been analyzed in the context of organization theory, such as origin and history, ownership and control, size, technology, location, and resources (e.g., Pugh, Hickson, Hinings, Macdonald, Turner, and Lupton 1963; Hickson, Pugh, and Pheysey 1969; Inkson, Pugh, and Hickson 1970; Child and Mansfield 1972). Purchasing research has adopted many of the concepts used in organization theory and identified causal relationships between factors internal and external to the organization and the structure of purchasing. Figure 4 illustrates the contextual variables that have been used to explain the structure of POs and shows that the variables can broadly be categorized into four groups.

\subsubsection{Organizational characteristics}

The first group contains variables that describe characteristics of the purchasing function or the organization as a whole. In this context, several authors analyzed the impact of organizational strategy on the structure of purchasing. Gianakis and Wang (2000), for example, showed that a customer orientation of the company favors decentralization in purchasing due to a higher degree of flexibility and shorter lead times. Similarly, Corey (1978) suggested that companies who closely cooperate with suppliers in product development should implement a decentralized PO to assure that purchasing competence can be kept in close geographic 
proximity to the supplier. Mattson (1988) further noted that the mission of the buyer, as formulated by management, is important for the structure of purchasing as well. If the primary mission of the buyer is cost reduction, the PO may be oriented more towards the realization of scale effects than in case quick decision making is set as the main objective. Lewin (2001) finally showed that efforts to reduce the head count in purchasing may lead to anxiety among purchasing employees, which induces the company to implement a more mechanistic structure in purchasing by using higher degrees of centralization and lower degrees of involvement.

Although buyer characteristics can be influenced by personnel management, some authors have treated employee characteristics as given and assumed that the characteristics of the purchasing agent cannot be influenced, which could be due to resource constraints, for example. In such a case, the PO has to be adapted to the capabilities of the buyer. Crow and Lindquist (1985) and Garrido-Samaniego and Gutiérrez-Cillán (2004) studied the impact of buyer characteristics on the structure of the buying center and showed that the education and knowledge of an individual participating in the purchasing process is negatively correlated to the size of the buying center (also Laing, Cotton, Joshi, Marnoch, McKee, and Reid 1998). They explain this by suggesting that a knowledgeable buyer will accept or need less external influence in making a purchase decision than a less knowledgeable individual. Dawes, Dowling, and Patterson (1992) hypothesized the same relationship, but were unable to confirm it empirically. Johnson, Leenders, and Fearon (1998b) further showed that organizations with the CPO represented on high hierarchical levels in the organization use more sophisticated purchasing techniques than organizations with the $\mathrm{CPO}$ on lower hierarchical levels, which may be traced back to the resources that can be made available for the purchasing function in the respective companies. A second contextual variable in this group is the size of the buying organization. While the size of the buying center has frequently been treated as a structural variable, the size of the buying organization, of which the buying center is a part, has been considered as a contextual factor. Obviously, researchers agree that the size of the buying organization is fixed, at least in the short term, wherefore it has to be taken as a

\section{Figure 4: Use of contextual variables in research on purchasing organization}

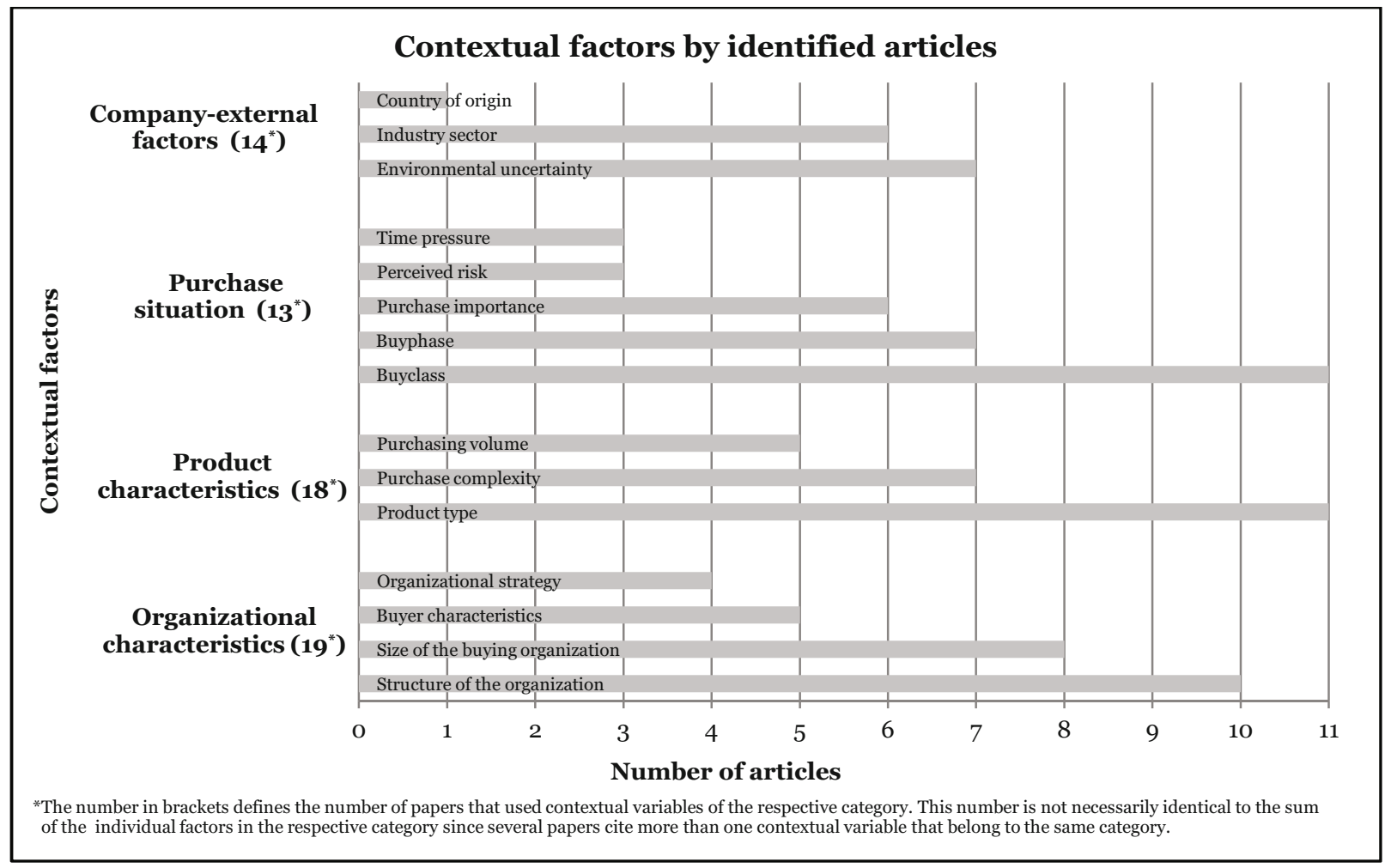


constant to which purchasing needs to adapt. In contrast, the size of the buying center may be influenced in the short term by assigning authority to additional employees or by withdrawing it, wherefore buying center size may be treated as a real decision variable. As to the size of the buying organization, large organizations are likely to have more available resources and provide a wider array of products and businesses than small organizations (Lynn 1987; Trent 2004), which may influence the PO. Further, it has been shown that organizational size increases departmentalization (Blau 1970), which may result in a higher degree of specialization. Therefore, some authors have analyzed the relationship between the size of the buying organization and the structure of the purchasing function and found that an increasing size of the organization leads to more individuals being involved in the purchasing process and consequently a larger buying center (Grønhaug 1975; Crow and Lindquist 1985; Lynn 1987; Dawes, Dowling, and Patterson 1992; Wood 2005), while other authors have not found a significant relationship (Johnston and Bonoma 1981a). Trent (2004) further studied whether the size of the buying organization influences the use of organizational design features and found that large organizations tend to have a more complex structure in purchasing than small organizations, which he traces back to the availability of resources and the regional scope of the companies as well (also Grønhaug 1976).

The last organizational characteristic in this group is the structure of the organization as a whole, which has been hypothesized to influence the organization of purchasing as well. Reasons for this relationship may be found in corporate policies and regulations which are reflected in the policies and regulations of the departments of the organization. Crow and Lindquist (1985) showed that an increasing size of the organization leads to an increase in the size of the buying center, while Dawes, Dowling, and Patterson (1992) were unable to confirm this effect empirically. Johnston and Bonoma (1981a); Dawes, Dowling, and Patterson (1992); Stanley (1993); Gianakis and Wang (2000) and Wood (2005) further showed that the degree of centralization, specialization, and formalization of the organization influences the degree of centralization and formalization of the purchasing function, respectively. Germain and Dröge $(1997,1998)$ found that a justin-time orientation of the organization leads to for- mal process descriptions in purchasing, while Gianakis and Wang (2000) showed that the use of performance measurement system fosters decentralization. Obviously, if employees are evaluated by quantitative performance measures and are held responsible for their performance, they are more likely to be granted greater decision authority (Lynn 1987 for similar results).

\subsubsection{Product characteristics}

The second group of variables contains characteristics of the products and services purchased by the organization. In this context, authors have hypothesized that an increasing purchasing volume leads to a higher savings potential and a higher importance of the purchase for the company (Grønhaug 1975; Corey 1978), which may impact the organization of purchasing. Grønhaug (1975) and Lynn (1987), for example, showed that the purchasing volume increases the size of the buying center, while Crow and Lindquist (1985) were unable to confirm this relationship. Corey (1978) hypothesized that a high purchasing volume results in a high degree of centralization due to an increased savings potential. Mattson (1988), in turn, found that a higher purchasing volume leads to more top-management involvement, which may again be a result of the importance of the respective purchases to the company. Obviously, with an increasing purchasing volume, organizations are more and more concerned about ensuring a proper use of funds, which leads to a more frequent use of control structures, such as top-management involvement or centralization.

A second product characteristic that has been studied as a contextual variable is purchase complexity, which is often defined as the technical complexity of the product and/or the complexity of the buying decision or task under consideration (McCabe 1987; Lewin and Donthu 2005). Complexity is assumed to induce uncertainty at the decision makers and to increase the need for using external sources of information (McQuiston 1989). Several researchers suggested that an increasing purchase complexity necessitates involving more individuals in the purchasing process to benefit from their expertise, which increases the size of the buying center. While Johnston and Bonoma (1981a) and GarridoSamaniego and Gutiérrez-Cillán (2004) found empirical support for this hypothesis, McQuiston (1989) and Dawes, Dowling, and Patterson (1992) 
found no significant relationship between the two variables. Further empirical support for the relationship between purchase complexity and the structure of the purchasing function was found by McCabe (1987), who showed that an increasing degree of complexity leads to a higher degree of centralization, which may be interpreted as an effort to ensure long-term availability of resources and to increase the role of technical specialists and management in the purchase decision. Kotteaku, Laios, and Moschuris (1995) found further support for this relationship and showed that the degree of influence depends on the phase of the buying process as well. Lau, Goh, and Phua (1999), in contrast, could not confirm a significant relationship between purchase complexity and the degree of structural complexity, formalization, and centralization of purchasing. A third product characteristic that has frequently been studied in prior research is the product type purchased by the organization. Many authors have classified products into different groups according to their function in the production process and presumed that the properties of the products influence the structure of purchasing. Grønhaug (1975); Johnston and Bonoma (1981a) and Mattson (1988), for example, categorized products by their influence on the organization's end product and showed that a high influence on the final product usually leads to a large buying center and a high level of topmanagement involvement in the purchase decision. This might be the result of efforts to avoid breakdowns in supply, and further technical characteristics of the products in question might necessitate involving technical specialists in the purchasing process which increases the size of the buying center. Other researchers further studied the impact of product type on the degree of centralization, formalization, and specialization. While Laios and Xideas (1994b) and Xideas and Moschuris (1998) came to the conclusion that highly important goods are associated with a high degree of the respective variables, Trautmann, Turkulainen, Hartmann, and Bals (2009) hypothesized a contrary relationship. Trautmann, Bals, and Hartmann (2009) further provided a portfolio model which defines product groups according to their strategic importance and their synergy potential and proposed that this model may be used in structuring POs as well. Finally, Naumann and Kim (1986) studied the impact of the technology used in manufacturing a product and showed that non-routine technology in the produc- tion process of a product is associated with a decentralized and little formalized purchasing function. The authors argued that non-routine technology requires quick decision-making, which in turn is only possible if decisions are made on low hierarchical levels, and rules and policies that are flexible enough to be adapted to changing conditions of a dynamic production environment.

\subsubsection{Purchase situation}

A third group of contextual variables which has been used in empirical studies refers to the characteristics of the purchase situation. In this context, researchers hypothesized that in case the employees involved in the purchase experience high time pressure, the structure of the purchasing function may be designed to enable quick decision making. Lau, Goh, and Phua (1999), for example, showed that an increase in time pressure reduces formalization of the PO and simultaneously increases its level of complexity and centralization. The authors argued that in order to speed up purchase decisions, specialized departments on relatively high hierarchical levels are necessary which have the information needed for completing the purchase readily available, and that formal regulations may be abolished to reduce the time spent on adhering to formal procedures. Garrido-Samaniego and Gutiérrez-Cillán (2004) further showed that time pressure is negatively related to the size of the buying center. This effect can be explained by the fact that a reduction in the number of employees participating in the purchase decision reduces the time required to complete the purchase. Dawes, Dowling, and Patterson (1992) hypothesized the same relationship, but were unable to confirm it empirically.

A second characteristic of the purchase decision is the risk involved in the purchase decision as perceived by the members of the organization. GarridoSamaniego and Gutiérrez-Cillán (2004) found that an increase in the perceived risk leads to a larger buying center, which may be interpreted as an effort to gain access to additional sources of information and to reduce the risk associated with the purchase decision. Dawes, Dowling, and Patterson (1992) hypothesized the same relationship, but were unable to confirm it empirically. Juha and Pentti (2008), in turn, studied the impact of the level of perceived risk on several structural variables of purchasing and found that a high level of perceived risk is associated with a high degree of centraliza- 
tion and a low degree of formalization and specialization. This may be an effort to increase the flexibility of the organization and to make generalist knowledge available, which is more important in a risky situation than specialist skills.

Another property of the purchase situation that may be related to the structure of the purchasing function is the importance of the purchase to the organization. Purchase importance may be defined as the impact of the purchase on different functional areas or individuals in the organization, on other purchases, or on the profitability and productivity of the company (Dawes, Dowling, and Patterson 1992). Several authors studied the relationship between purchase importance and buying center size and showed that the importance of a purchase is positively related to the size of the buying center (Johnston and Bonoma 1981a; McQuiston 1989; Dawes, Dowling, and Patterson 1992; Garrido-Samaniego and Gutiérrez-Cillán 2004). The authors argued that in case a purchase is considered important by the organization, more technical personnel and specialists are involved in the process, which increases the size of the buying center. Johnston and Bonoma (1981a) and Lau, Goh, and Phua (1999) further showed that an increase in purchase importance leads to an increase in complexity, formalization, and centralization, which they identified as measures to assure that the objectives of the company are achieved and the information required for the purchase is readily available.

A fourth contextual variable in this group is the buyphase, which defines the decision process from problem recognition through intermediate steps, such as search for a supplier and contract award, to the post-purchase stage (Mattson 1988). As suggested by Juha and Pentti (2008), perceived risk and uncertainty increase in the course of the purchasing process, wherefore it is likely that the structure of the buying center is different for various stages of the purchasing process. Lynn (1987) and McWilliams, Naumann, and Scott (1992), for example, found in an empirical study that more individuals are involved in earlier stages of the buying process, while Johnston and Bonoma (1981b) were unable to identify systematic differences in buying center size along the stages of the purchasing process. Laios and Xideas (1994a,b) and Juha and Pentti (2008) further studied the characteristics of several structural variables along the stages of the buying process. While Laios and Xideas (1994a,b) found centralization to be lower at the end of the purchasing process and specialization and formalization to be lower at the beginning, Juha and Pentti (2008) drew opposite conclusions. The differences in the results reflect the perceptions of the 'contingency view' and the 'constriction of authority view' of organization theory, which propagate different ways for managing uncertainty through organizational design (McCabe 1987).

A last characteristic of the purchase situation that was studied in prior research is the degree of novelty of the purchase. Several authors adopted the buyclass framework of Robinson, Faris, and Wind (1967), which hypothesizes that in a repeated purchase, the buying problem will be more versed and structured and easier to handle as compared to a new buying situation which results in a situation of unfamiliarity and insecurity. Grønhaug (1975); Crow and Lindquist (1985); McQuiston (1989); McWilliams, Naumann, and Scott (1992) and Garrido-Samaniego and Gutiérrez-Cillán (2004) found that the size of the buying center is larger in new buy situations than in repeated purchases, which could be an effort to make additional information and experiences available and to reduce uncertainty connected with the purchase. Johnston and Bonoma (1981a); Lynn (1987); and Dawes, Dowling, and Patterson (1992) hypothesized the same relationship, but were unable to confirm it empirically. Lau, Goh, and Phua (1999) and Juha and Pentti (2008) finally studied the relationship between the novelty of a purchase and several structural variables of purchasing. While both works identified a positive relationship between both the degree of novelty and complexity and the degree of centralization of the buying center, Lau, Goh, and Phua (1999) found a negative correlation between novelty and formalization. Juha and Pentti (2008), in turn, identified a positive correlation between these variables. The variation in the structural variables may again be interpreted as an effort of the organization to solicit relevant experiences and knowledge and to reduce uncertainty associated with the purchase.

\subsubsection{Company-external (environmental) factors}

Figure 4 indicates that three variables have been used in prior research to describe the environment the buying company operates in. First, Quintens, Matthyssens, and Faes (2005) studied the impact of a company's country of origin on the structure of purchasing by comparing companies from Belgium 
and the US in a case study. He noted that US companies have a stronger tendency towards individualism and are more sensitive towards price than Belgian companies, which tend to rely on power structures and focus on quality and availability. He hypothesized that the country of origin influences the organization of purchasing, but found that POs in both countries did not differ significantly.

Second, several authors analyzed the impact of the industry structure on the structure of purchasing. In this context, several authors analyzed similarities and differences between the $\mathrm{PO}$ in public-sector and private organizations and found that public institutions tend to have larger buying centers and use a higher degree of specialization and complexity in organizing their purchasing function (Crow and Lindquist 1985; Laios and Xideas 1994a). Further, public institutions tend to use a higher degree of formalization and involvement of supervising bodies (Laios and Xideas 1994b). The difference might be caused by legal regulations, which require that public funds have to be spent transparently and which necessitate a formal and complex public purchasing process. Johnson, Leenders and Fearon (1998a) and Johnson, Klassen, Leenders, and Fearon (2002) studied the structure of purchasing in service and manufacturing industries and found that service firms are more often centralized than manufacturing companies and that purchasing teams that involve customers prevail in the service industry. In contrast, manufacturing companies have a stronger tendency to (partially) decentralize their purchasing activities and use purchasing teams solely made up of members of the organization. The authors explained this difference with the importance purchasing enjoys in the respective industries, since purchasing accounts for a higher percentage of sales in manufacturing than in service industries, and with a stronger need to involve customers in the purchase decision in service organizations. These results contrast those of Grønhaug (1976), who discovered no differences in the composition of the buying center in product-dependent and product-independent organizations. Juha and Pentti (2008) finally studied differences in the purchasing structure of high-tech companies and companies not operating in a high-technology environment and found that high-tech companies tend to be less formalized and specialized than less technology-oriented organizations, which they ascribed to a higher need for flexibility in the high-tech sector.
Finally, several authors analyzed the relationship between environmental uncertainty and a number of structural variables. As uncertainty increases, organizations may decide to implement a more flexible and less bureaucratic structure to facilitate a free flow of information (Spekman and Stern 1979). The results of the studies are ambiguous: while some studies found a negative relationship between the degree of environmental uncertainty and the level of formalization of purchasing (Spekman and Stern 1979; Klebba and Dwyer 1981; Thomas and Grashof 1982; Lau, Goh, and Phua 1999), conflicting relationships have been reported between environmental uncertainty and other structural variables, such as centralization, specialization, complexity, or the size of the buying center (Appendix H). McCabe (1987) argued that these differences may be due to the operationalization of the constructs used, wherefore he suggests differentiating between perceived and objective uncertainty. In an empirical study, he identified a positive relationship between perceived uncertainty and centralization and a negative relationship between perceived uncertainty and buying center size, but was unable to find a correlation between uncertainty and formalization.

\subsection{Purchasing structure as a contextual variable}

Besides studying determinants of POs, several authors have dealt with the organizational types of purchasing (discussed in the next section) or certain structural variables as a contextual variable and analyzed their impact on several characteristics of the company (Appendix $\mathrm{H}$ for a list of works that study purchasing structure as a structural variable). The relationship was analyzed by Johnson, Leenders, and Fearon (1998b) and Johnson, Klassen, Leenders, and Fearon (2002), who studied the degree of centralization as a determinant of the use of different purchasing techniques and the strategic impact of purchasing on the company. Their results indicate that centralized purchasing departments exert a higher influence on major corporate activities than decentralized departments and consequently enjoy a higher strategic role. Further, they showed that more sophisticated purchasing techniques were used in centralized departments, which may be the result of greater financial and personnel resources which are commonly available in centralized departments. A second relationship studied in prior works is the impact of different structural 
designs of the PO on the performance of the company, which will be discussed below. For studies that analyzed the relationship between the structure of the purchasing function and the size of the purchasing task group, the reader is referred to Naumann and Kim (1986), and for an analysis of structure's influence on the buying center to Webster and Wind (1972).

\subsection{Organizational types of purchasing organizations in private institutions}

Besides discussing determinants and structural characteristics of the purchasing function, authors have developed conceptual models of alternative institutional types of POs and studied their use in practice. According to Mintzberg (1980, 1981, 1991), institutional types are natural clusters or configurations of design parameters in line with their contingency factors. Ketchen, Thomas, and Snow (1993) described institutional types as clusters of attributes of organizational strategies, structural variables, and processes. Figure 5 gives an overview of the different types analyzed in prior research on POs in private institutions and shows that the concepts can be categorized into four groups. A fifth set of articles provides typologies of POs in the private sector. The following section presents the characteristics of the established institutional types and briefly discusses their importance for purchasing research.

\subsubsection{Sourcing teams}

Purchasing teams have enjoyed an increasing popularity among both practitioners and researchers in recent years (Pearson 1999; Ellram and Pearson 1993). Teams, in this context, can involve members of the organization, suppliers or customers, and aim at making knowledge for the purchase available and on integrating purchasing into other functional areas of the organization, in particular new product development (Johnson and Leenders 2006). Sourcing teams have been differentiated into purchasing councils, supplier councils, commodity teams, consortium buying, cross-functional teams and teams involving suppliers, customers, or both suppliers and customers. Prior research can roughly be divided into two research streams.

The first stream of research studied the degree of team usage in purchasing. Thereby, authors attempted to identify factors that influence the use of teams in purchasing and found that factors such as the novelty and volume of a purchase (Grønhaug 1975), the structure of the organization as a whole and the characteristics of the CPO (Johnson, Leenders, and Fearon 1998b) as well as industry context and firm size (Johnson, Klassen, Leenders, and Fearon 2002) are critical determinants of team usage. The results of the studies indicate that teams are especially used in case complex purchases necessitate joint decision making and/or the

Figure 5: Institutional types of purchasing organizations in private institutions

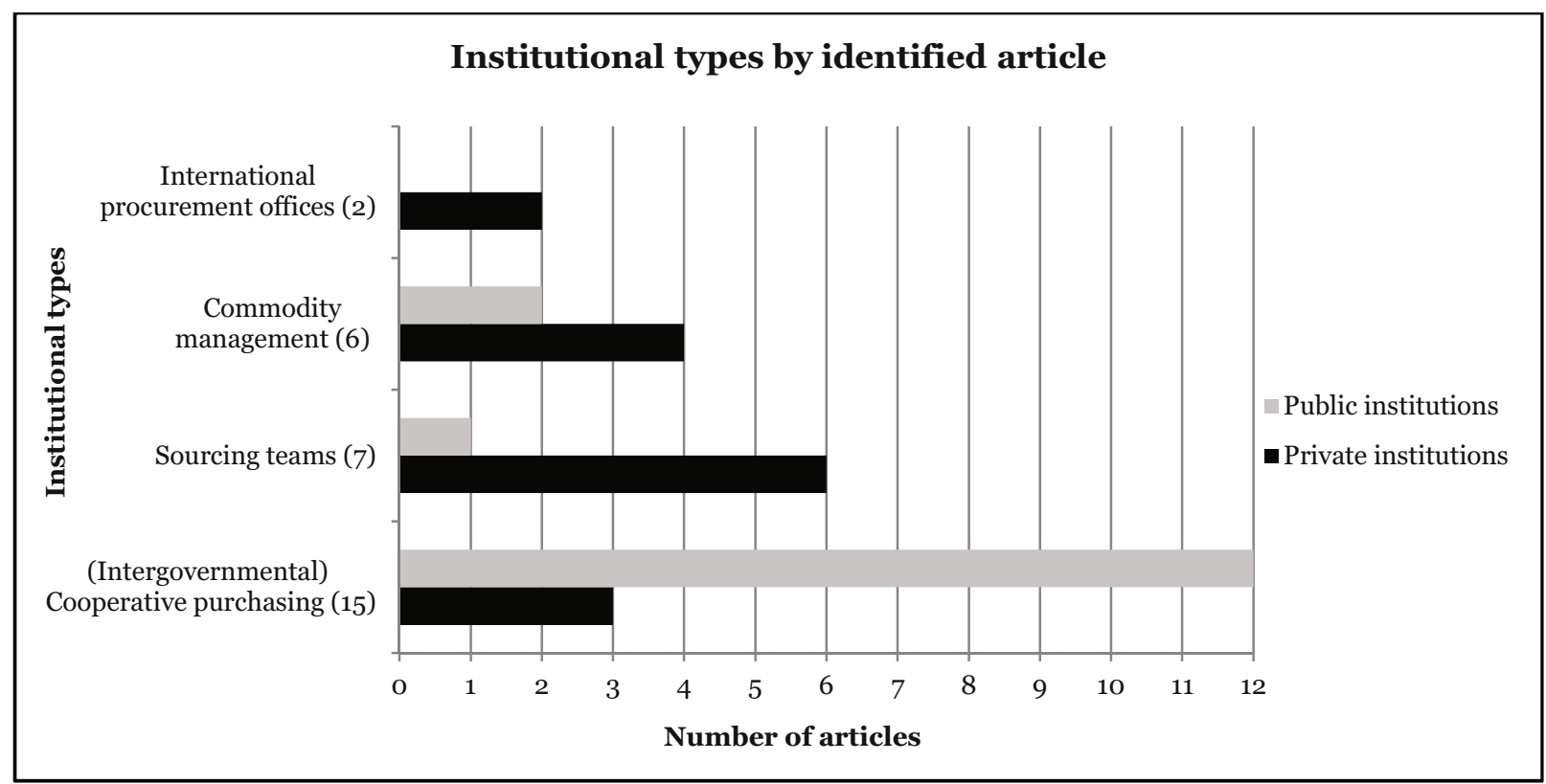


areas. Changes in the use of purchasing teams were studied by Johnson and Leenders (2006), who reported large decreases in the use of supplier councils, teams with external customers, and teams with suppliers and external customers. Significant increases could be found for consortium buying, commodity teams, cross-functional teams and colocation of purchasing personnel.

A second stream of research identified success factors of cross-functional sourcing teams and member motivation. Trent and Monczka (1994), for example, analyzed factors that impact cross-functional sourcing team performance. The results of their study indicate that the most important success factors of sourcing teams are the availability of key organizational resources, participation and involvement of selected suppliers, levels of internal and external decision-making authority, effective team leadership, and the effort spent on the assignment of teams to tasks. Based on this research, Trent (1996) studied the relationship between the sourcing team leader and team performance and showed that team performance depends on the effectiveness of the formal team leader. To facilitate team leader selection, the author developed three assessment scales which may be used in evaluating a sourcing team leader's ability to satisfy critical leadership requirements. In a follow-up study, Trent (1998) discussed the relationship between member effort and sourcing team effectiveness. The author hypothesized that especially in case employees are only assigned to teams on a part-time basis, promoting motivation and commitment is a critical success factor.

\subsubsection{Commodity management}

Commodity management is defined as a centrally coordinated institutional type that develops and implements company-wide strategies for a given product or service category (Englyst, Jorgensen, Johansen, and Mikkelsen 2008). Their use in companies that engage in $\mathrm{R} \& \mathrm{D}$ partnerships with suppliers was studied by Nellore and Motwani (1999), who reported quality improvements at the supplier, higher supplier motivation, an improved knowledge base of the commodities concerned as well as substantial cost savings for companies relying on commodity management. Based on a case study, they further proposed a concept for the organization and management of purchasing projects in outsourced product development through commodity managers.
Englyst, Jorgensen, Johansen, and Mikkelsen (2008) discussed functional and motivational mechanisms in commodity management, with the intention to identify factors that influence team member motivation. The results showed that compensation and reward systems, leadership behavior and effectiveness as well as goal setting and career goals are major determinants of motivation. Inconsistencies between these factors and the objectives of the commodity groups were hypothesized to result in reduced performance. Trautmann, Bals, and Hartmann (2009) and Trautmann, Turkulainen, Hartmann, and Bals (2009) further addressed drivers of global integration of product categories and derived category selection criteria and implementation guidance for designing the global sourcing organization.

\subsubsection{International procurement office}

To manage international sourcing activities efficiently, companies started to establish so-called 'international procurement offices' (IPOs) in key markets as a strategy to remain globally competitive (Goh and Lau 1998; Carduck 2000; Nassimbeni and Sartor 2006). With offices in important supply markets, companies can gather information about suppliers and supply conditions easier and react more quickly to changes in the market, which may result in better PP.

Goh and Lau (1998) described the concept of IPOs by evaluating their functions and operations in the dynamic Asian economies with a special focus on the electronics industry in Singapore. The authors showed that newly established IPOs often assume purely representative functions, while more mature IPOs are often responsible for performing purchases as well. In most of the cases studied, IPOs were staffed with highly qualified, local employees. Based on a literature review, Nassimbeni and Sartor (2006) proposed guidelines for establishing and managing IPOs in China. Further, they developed a framework for assigning main functions to the IPOs by taking the characteristics of the Chinese normative, social and political context into consideration.

\subsubsection{Cooperative sourcing (purchasing groups)}

'Cooperative sourcing', 'purchasing consortia' and 'purchasing groups' are often used synonymously in the literature to define the cooperation between two or more organizations in purchasing. Organizations engaging in cooperative sourcing share and/or bun- 
dle their purchasing volumes, information, and/or resources in one or more steps of the purchasing process and combine their individual requirements to achieve mutually compatible goals and competitive advantages (Schotanus and Telgen 2007). Purchasing groups may be formal or informal arrangements and consist of dependent or independent organizations in which cooperative supply processes proceed (Schotanus and Telgen 2007). Prior research can be divided into two research streams.

The first research stream developed theoretical frameworks and typologies for cooperative sourcing. Essig (2000), for example, examined the state of the art in research on consortium purchasing and introduced consortium sourcing as a theoretical supply management concept combining symbiotic horizontal relationships and strategic perspectives to gain competitive advantage. He classified cooperative sourcing as one element of a supply strategy and as the antipode to individual sourcing. As a 'subject supply strategy', it may be combined with other effective sourcing strategies such as global, single or system sourcing. Performance implications of cooperative sourcing will be discussed below. Schotanus and Telgen (2007) developed a typology for purchasing groups by discussing specific organizational forms for collaborative procurement which differ by the degree of influence group members have on the activities of the group and the range of activities performed by the group. The typology may be used for selecting an appropriate organizational design for cooperative sourcing.

A second stream of research identified motives and critical success factors for purchasing partnerships. Tella and Virolainen (2005) discussed motives for industrial companies for participating in purchasing cooperations. The results indicate that there are two main reasons for cooperative sourcing: cost savings and better access to information on supply markets and potential suppliers. Cost savings are mainly due to fewer transactions and increased negotiation power, which results in lower purchase prices.

\subsubsection{Typologies of organizational models in private institutions}

Above, we introduced the degree of (de)centralization as the most frequently discussed structural variable in purchasing research. Building on this research stream, Arnold (1999) studied ways to determine an optimal degree of purchasing configuration by integrating the effects of internalization and centralization on the company and functional level. Based on these two dimensions, he identified three clusters with idealized types of organizations for effective global sourcing: He concluded that the central purchasing model is best suited for organizations with generally low international/global sourcing activities and a high degree of centralization, while the coordination model should be used by centralized, internationally active companies. The outsourcing model is finally appropriate for highly decentralized, internationally oriented companies.

Hartmann, Trautmann, and Jahns (2008) developed a classification of POs and differentiated between global and transnational companies. While global companies have headquarters which dominate the purchasing process, transnational companies rely on integrated purchasing networks. With the help of a case study, the authors showed that the first group of companies uses a high degree of centralization to organize their purchasing activities, while the PO of the second group is less centralized. Further, they showed that both groups use a medium degree of formalization in organizing their purchasing function. An alternative classification was proposed by Cavinato (1992), who defined seven basic models for purchasing under the assumption that procurement is a support function of logistics.

\subsection{Organizational types of purchasing organizations in public institutions}

Research on the PO has not only studied privately owned companies, but has paid attention to the purchasing function of public institutions as well. Since the procurement process in the public sector is subject to a different legal framework than private purchases, and since public institutions typically pursue a different set of goals than private companies (for an overview Telgen, Harland, and Knight 2007), it is reasonable to assume that differences in the PO exist. Laios and Xideas (1994a) and Johnson, Leenders, and McCue (2003), for example, compared the PO in public and private institutions and showed that the structure of purchasing is more complex and formalized in public than in private institutions, which may be due to the fact that public institutions use public funds and have to ensure transparency and accountability. Johnson, Leenders, and McCue (2003) further showed that public institutions tend to rely on a higher degree of centralization in organizing their purchasing activi- 
ties, which may be a result of efforts to reduce variability in the purchasing process and to ensure that employees adhere to formal process descriptions and the regulations of public procurement law. Research on the organization of public purchasing can be grouped similarly than research on the organization of purchasing in the private sector. Figure 5 gives an overview of the different institutional types that have been analyzed in prior research and shows that the concepts can be categorized into three groups. It becomes apparent that most institutional types that have been studied in private organizations have been studied in the public sector as well, with the exception that IPOs have not been discussed for public institutions. This is obvious as public institutions are subject to public procurement law, which necessitates that public tendering procedures have to be applied and which permits international sourcing activities only to a very limited extent.

\subsubsection{Sourcing teams}

Johnson, Leenders, and McCue (2003) analyzed the use of sourcing teams in public institutions and compared their results with studies that focused on the private sector. The results indicate that sourcing teams are less frequently used in public than in private institutions. This may be attributed to the fact that public institutions are not active in new product development, which is a typical field of application for purchasing teams. However, the authors found that public institutions tend to use teams that involve internal customers, which may be due to the requirements of the public purchasing process, where purchasing agents have to formulate tender documents which contain detailed information about product characteristics, while expert knowledge is located in the requiring units. This necessitates a close cooperation between the purchasing agent and the internal customer.

\subsubsection{Commodity management}

Bacon (1971) studied the PO in academic institutions and developed a role model for the purchasing function of universities. He emphasized that universities predominantly purchase finished products, which differentiates them from private companies which often purchase raw materials as well. He suggested that purchasing should use commodity teams for different material groups to facilitate meeting the requirements of the university's de- partments. In contrast to Bacon (1971), Call (1968) concluded that commodity management is unsuitable for academic institutions and that purchasing should be organized along departmental lines, such that purchasing agents should be assigned to purchase the requirements of particular departments to optimize service to the requiring units. It is obvious that both alternatives, i.e. an organization using commodity management and an organization along departmental lines, have their respective advantages and disadvantages and that public institutions have to weigh the trade-off between cost effectiveness and customer service when deciding which organizational form to use.

\subsubsection{Intergovernmental cooperative sourcing (public purchasing groups)}

'Intergovernmental cooperative purchasing' (IGCP) is a special form of cooperative sourcing, where public agencies jointly purchase. Nollet and Beaulieu (2005) defined a purchasing group as a formal or virtual structure that facilitates the consolidation of purchases for many organizations. Consolidation refers to a procurement practice used to transfer activities such as bidding, supplier evaluation or contract management to a central entity. IGCP is characterized as 'a strenuous workout in human relations and inter-governmental relationships' (Belmonte 1972). Since public institutions are normally not in direct competition with each other, collaborative purchasing initiatives are more common in public than in private institutions (Johnson, Leenders, and McCue 2003) and have consequently received increased attention in recent years (e.g., Johnson 1999; Essig 2000). Thereby, prior research has focused on two main topics.

First, authors have discussed reasons for establishing IGCPs and developed theoretical frameworks for the management of purchasing consortia. Belmonte (1972), for example, carried out a case study of consortium purchasing in the US. He briefly described the composition of the consortium, functions performed by the consortium and factors affecting the success of cooperative sourcing. Johnson (1999) examined how and why public purchasing consortia are created and found that cost reduction is the main reason for public administrations to engage in cooperative purchasing. Further, the author presented a five-phase life-cycle framework to explain the evolution of public-sector purchasing consortia. Nollet and Beaulieu $(2003,2005)$ reported the use 
of purchasing groups in the healthcare sector in the US and Canada and suggested that purchasing authority could either be transferred to a separate and autonomous entity, or that the contracts to be negotiated could be shared among the members of the group. While the first alternative is associated with additional costs for hiring the external entity, the second alternative leads to a high coordination effort especially if the group size is large. Bakker, Walker, Schotanus, and Harland (2008) developed a theoretical framework and evaluated the two basic forms of collaborative procurement introduced by Nollet and Beaulieu (2003) with regard to their impact on organizational costs. With the help of this framework, decision makers are able to assess which form of collaborative procurement leads to the lowest organizational costs for a specific purchase situation. Further data on the prevalence of collaborative procurement initiatives in the public sector can be found in Hardwick (1969) and Fearon and Ayres (1967).

Second, prior work attempted to identify success factors of public cooperative sourcing. Steinhauer (1972, 1976), for example, reported ten characteristics of a successful IGCP organization and identified a profile of the typical local governmental purchasing officer. Doucette (1997) and Laing and Cotton (1997) further studied group purchasing organizations (GPOs) in the healthcare sector. Their results indicate that important success factors of GPOs are member commitment and information exchange, trust, common objectives and interests, communication, and conflict management.

\subsubsection{Typologies of organizational models in public institutions}

A typology of POs in the public sector was proposed by Kamann (2007), who used a stakeholder approach to define four archetypes of public POs. He defined organizations supplying innovative products under user intimacy as teams, while organizations providing standard services under operational excellence were defined as squeezers. Organizations that use a medium degree of product innovativeness/user intimacy were defined as star + satellites and flexibilizers. For all four archetypes, he defined organizational characteristics which were aligned to the requirements of the respective purchasing situation.

Schotanus and Telgen (2007) developed a classification of alternative forms of cooperative purchasing for public institutions. First, they defined five role models of cooperative sourcing and then characterized these models with respect to the influence of their members on the purchase decision and the number of different group activities performed. They showed that in case only a few activities need to be performed and a high influence on the purchase decision is not necessary, an informal, shortterm purchasing cooperation is best suitable. If, in contrast, a high number of group activities need to be performed and each participant wants to influence the purchase decision, a formal purchasing group which focuses on the reduction of transaction costs is recommended.

A final typology was proposed by Farrer (1969), who studied purchasing at the US Army and developed models for two alternative sourcing structures, one that focuses on the requirements of the end user and one that aligns the structure along technical characteristics. A case study conducted by the author indicated that the first structure might perform better in the military procurement function than the second.

\subsection{Performance impact of the purchasing organization}

The literature on strategic purchasing has shown that the supply function can have a significant impact on firm performance (Carr and Smeltzer 1999, Carr and Pearson 2002). In addition, Milgrom and Roberts (1992: 16-17); Stanley (1993) and March and Sutton (1999) hypothesized that the structure of a company is a critical determinant of performance as well. By combining both ideas, researchers have analyzed the impact of purchasing's organizational design on the performance of the firm and the performance of the purchasing agent. With reference to the analytical framework developed above, prior work can be categorized into works that study the impact of a) alternative combinations of structural variables, b) the relationship between structural variables and contextual variables, and c) different institutional types on PP and in part on the performance of the entire company.

In the first category, Stanley (1993) hypothesized a relationship between the PO and PP and assumed that alternative organizational designs, characterized by varying degrees of centralization, formalization and complexity, will perform differently under changing environmental conditions. PP is conceptualized with efficiency, effectiveness and adaptive- 
ness as performance measures. Kolchin (1986) examined the relationship between the PO and the performance of the department store purchasing agent. PP of the purchasing agent is measured in terms of flexibility of the purchasing agent (indicator for adaptiveness), formalization of the purchasing agent's position (indicator for effectiveness) and instrumental leader behavior of the purchasing agent's supervisor (indicator for efficiency). The results of the study indicate that agents who performed best were working in highly structured environments, i.e. in a purchasing function characterized by a high structure of the individual, the position, guidelines specified by the leader, and the task itself. Trent (2004) found that a higher-level procurement officer is critical to organizational design effectiveness. Based on the methodology adopted by Trent (2004), Tirimanne and Ariyawardana (2008) studied the impact of twenty-three organizational design features on PP. Their results indicate that the degree to which sophisticated organizational design features for purchasing are used (i.e. the degree to which purchasing is structured) is positively correlated with PP. Companies that used appropriate design features exceedingly achieved better PP than companies that relied on a simple PO. SanchezRodriguez, Hemsworth, Martinez-Lorente, and Clavel (2006) finally studied the impact of standardization on purchasing and business performance and showed that standardizing materials and purchasing processes has a positive impact on PP and the company as a whole. Tirimanne and Ariyawardana (2008) and Sanchez-Rodriguez, Hemsworth, Martinez-Lorente, and Clavel (2006) conceptualized PP considering objective performance measures identified by Chao, Scheuing, and Ruch (1993). Tirimanne and Ariyawardana (2008) used all five efficiency-oriented measures 'on-time delivery', 'accuracy of purchasing', 'quality of purchased items', 'actual material cost vs. total processing cost' and 'purchasing order cycle time', while SanchezRodriguez, Hemsworth, Martinez-Lorente, and Clavel (2006) used 'quality of materials purchased', 'on-time delivery', and 'actual versus target materials cost' as well and 'inventory performance' referring to internal customer satisfaction, in addition.

In the second category, David, Hwang, Pei, and Reneau (2002) examined the contingency effect between product competitive strategy adopted at corporate level and the organizational design as independent and purchasing and firm performance as the dependent variable. Their results indicate that a significant relationship between the independent variables and financial performance indicators of the firm exists. Measures of purchasing operational efficiency are 'purchasing amount per dollar of purchasing operating expenses', 'purchase amount per employee', and 'inventory turnover', while the financial performance is measured as 'return on assets'. The authors concluded that firms pursuing a cost strategy should adopt a centralized purchasing structure, while firms pursuing a differentiation strategy can improve performance by decentralizing the supply function.

In the third category, Essig (2000) finally investigated the performance effect of consortium purchasing on the consortium's shareholder value by using Rappaport's shareholder value approach and the discounted cash flow method (indicator for efficiency). The results of a case study indicate that cooperative sourcing helps to lower transaction costs in the long run if a symbiotic structure can be established. The position of the consortium will be improved by establishing interaction structures to realize economies of scale in purchasing. In addition, the author identified a positive correlation between the number of interactions and the performance of the consortium. Reck and Long (1983) finally studied the impact of a profit and cost center structure of purchasing on firm performance and developed a four-step process which helps companies to change the structure of purchasing from a profit center to a cost center.

\section{Research limitations and research directions}

This paper conducted an extensive review of works that studied the organization of purchasing. This section identifies research gaps and proposes potential research topics which may be objects of interest for researchers in the future. Figure 6 summarizes the findings.

\subsection{Structural characteristics and determinants of purchasing organizations}

The discussions above illustrated that a large number of researchers have studied structural variables of the purchasing function and determinants of the PO. Our literature review showed that prior research has developed concepts that describe the 
structural design of purchasing in detail, and that several contextual factors that impact the PO could be identified. However, two research gaps became apparent that may be approached in future research: First, several hypothesized contingency relationships between contextual variables and the structure of the purchasing function led to inconsistent results. This aspect was discussed previously by Lewin and Donthu (2005), who conducted a meta-analysis which studied how certain study design characteristics influenced the relationship between the contextual and structural variables. Their results indicate that a significant relationship could only be found between some of the variables and that divergent study design characteristics likely led to biases. Future research could concentrate on further studying inconsistencies and try to further our understanding of which situational factors influence the PO. Second, we found that prior research has concentrated on a relatively small number of contextual variables which have been used in explaining the structure of the purchasing function. We note that the literature on organizational design describes a larger variety of contextual variables than have thus far been applied in purchasing research. For example, we may assume that the degree of internationalization of a company's purchasing activities or legal regulations of the supply market the company is active in may influence the $\mathrm{PO}$ as well, that POs may differ from country to country due to legal or cultural factors or that the use of IT technology impacts the organization of purchasing as well. Further, it has been shown in prior research that the interaction of purchasing with other functional areas of the company is becoming more and more important. However, prior research did not analyze how the purchasing function should be structured in light of its interaction with other corporate functions. Thus, considering the interfaces between purchasing and other functional areas as a contextual variable seems to be promising. In general, future research could concentrate on identifying additional contingency relationships which would further our understanding of which factors have to be, and which do not have to be, considered in designing a PO.

\subsection{Organizational types of purchasing in private institutions}

Above, we showed that a large number of articles analyzed alternative institutional structures of pur- chasing. Our analysis illustrated that prior research concentrated on developing specific concepts for the structure of purchasing and focused on cooperative sourcing activities. However, several types of POs that can be found in practice have received limited attention in prior research, such as the lead-buyer concept or shared service centers. Future research could concentrate on analyzing these purchasing structures by defining concepts and by studying how these organizational forms are used in practice. In addition, we identified a need for developing more comprehensive typologies of POs to differentiate alternative structural designs, reduce ambiguity in the use of terminology and facilitate the selection of appropriate design alternatives in practical scenarios. Further, we note that the change of institutional structures in purchasing over time has thus far only been analyzed by a few authors (Johnson, Leenders, and Fearon 1998a; Johnson and Leenders 2001; Johnson and Leenders 2004; Johnson, Leenders, and Fearon 2006) and that further research is necessary to explain how and why POs change over time. Finally, we identified only a single work (Nellore and Motwani 1999) which addresses the change management process and related requirements in POs. We suggest that future research could transfer the findings from traditional change management research to the PO.

\subsection{Organizational types of purchasing in public institutions}

Although several authors have focused on analyzing the PO in public institutions, prior research has fallen short in explaining how the characteristics of the public purchasing function impact the structure of purchasing. Our analysis showed that especially the use of teams and the commodity management concept in public institutions has received limited attention so far. Thus, we suggest that future work could concentrate on analyzing patterns in the use of both concepts in public institutions and try to identify factors that differentiate teams and commodity management in public institutions from POs that prevail in private companies. Further, our analysis showed that prior work has not focused on the impact of public procurement law on the structure of public purchasing, which seems to be another promising area of future research. In addition, as noted by Johnson, Leenders, and Fearon (2006), future research could study supply organization roles and responsibilities in large government buy- 
ing organizations, which has not been done yet. Finally, we found that prior research has not differentiated adequately between different types of public institutions, and that an analysis of differences in the organization of purchasing in public hospitals, universities and public companies, for example, would be interesting. The work of Glock and Broens (in Press), who studied the organization of purchasing at universities, could serve as a starting point for such an analysis.

\subsection{Performance impact of the purchasing organization}

The impact of supply management on the firm's performance has frequently been discussed in the past (Chen, Paulraj, and Lado 2004; Bernardes and Zsidisin 2008; Baier, Hartmann, and Moser 2008). However, we note that the performance impact of the purchasing structure has only infrequently been studied thus far. Our analysis identified only eight papers dealing with the relationship between the structure of purchasing and performance outcomes. In total, we identified several research gaps that need to be addressed in future research: First, we suggest that researchers should address the issues of operationalization and measurement of organizational performance in purchasing. As shown in Figure 1, efficiency, effectiveness and adaptiveness are possible measures of company performance. However, a better understanding of these terms is needed for measuring consistently and for avoiding methodological pitfalls. Further, as was already noted by Stanley (1993), adaptiveness has often been neglected in research on the performance impact of $\mathrm{PO}$, which needs to be rectified in the future. Second, authors could concentrate on studying the contingency relationships between supply strategies and strategic supply management, on the one hand, and different POs and financial performance of the firm, on the other (e.g., David, Hwang, Pei, and Reneau 2002; Quintens, Pauwels, and Matthyssens 2006b; Tirimanne and Ariyawardana 2008). Third, a focus on the impact of contextual variables on PP would shift the debate from 'good performance vs. poor performance' to one of 'performance under certain conditions.' Fourth, future research could focus on the effect of the PO on the purchasing agent's performance. Under the assumption that purchasing agents will perform with different degrees of effectiveness under alternative environmental and organizational design conditions, highlight- ing the contingencies of purchasing effectiveness and the organizational and environmental determinants under which purchasing agents perform most efficiently seems to be promising. Finally, we found that prior work has neglected the performance impact of POs in the public sector. As explained above, public institutions follow a different set of goals than private institutions, wherefore we may assume that performance measurement concepts which have been developed for assessing different organizational designs in private purchasing may not be used without modification in the study of public institutions.

\subsection{Theoretical research on the organization of purchasing}

Our descriptive analysis showed that several authors used established theories to explain the organization of purchasing. However, since only a small fraction of the works published in this area are adequately theory-based, we conclude that future research should concentrate more on using theories for explaining the PO. From our analytical framework, we can derive the following research propositions:

First, it would be interesting to study how the PO impacts motivation and control in purchasing. It can be assumed that employees are normally driven by self-interest and that motivation and control systems are necessary to induce them to act in the interest of the company (e.g., Milgrom and Roberts 1992: 388-421). The PO can influence the motivation of employees by assigning tasks to members of the organization and by influencing the work environment, wherefore we may assume that alternative structural designs for purchasing lead to different degrees of employee motivation. In this context, it would be especially interesting to study the PO from the perspective of principal agent theory or game theory to derive guidelines that help to structure the PO in order to reduce hold-up potential in internal and external relationships and to motivate the purchasing employees.

A second aspect that has not received enough attention is the fact that the internationalization in purchasing may lead to complexity-related problems. It is obvious that in case a company decides to run branch offices in geographically dispersed regions, coordinating the PO becomes increasingly difficult (e.g., Glock and Bogaschewsky 2009). In addition, the complexity within the PO increases considering 
the heterogeneity and diversity of contextual factors in an international environment. Thus, we recommend analyzing the PO of multinational companies from the perspective of complexity theory (Crozier and Thoenig 1976) to derive guidelines that help to decide on where in the company network purchasing authority should be located and that helps to reduce system complexity.

A third aspect that would be worth investigating is the question of whether to outsource purchasing or to keep it in-house. In this context, it is interesting to study to what extent purchasing may be considered as strategic (e.g., Ramsay 2001; Mol 2003) and how outsourcing of purchasing impacts the competitive position of the company. The resource-based view, the relational view and transaction cost theory may offer interesting insights on this issue.

Finally, in light of the performance discussion presented above, it would be interesting to develop theoretical performance measures for POs in addition. When the PO is seen as a bundle of internal organizational resources (Barney 1991), which help to achieve competitive advantage, the scales for competitive-oriented measurement can be developed based on the resource dimensions 'value', 'scarcity, 'imperfect imitability', and 'nonsustainability'. Interpreting the PO as a hybrid organizational form (Williamson 1981) that focuses on the minimization of transaction costs, the transaction cost dimensions could be used to construct a cost-oriented performance measure.

These are four examples that illustrate how our understanding of the structuring of purchasing may be enhanced by theory-based research. It is obvious that the use of other theories not discussed here, e.g., the social exchange theory, behavioral models or the self-organization concept, could lead to interesting insights as well.

\section{Limitation of the literature review and conclusion}

\subsection{Limitations of the analytical framework}

In the analytical framework, only the impact of the environment on the PO was considered, while the influence of the organization on the environment was excluded from the analysis. Further, the organization of purchasing was interpreted from a hierarchical, and not from a process-oriented perspective. To address these limitations, the theoretical frame- work would have to be extended. First, we suggest incorporating a reward/measurement component of buying behavior based on the ontological framework of Anderson and Chambers (1985) as a further organizational dimension. Second, as the analysis of organizational structure was conceptualized ignoring the 'social structure' of the buying center (Blau 1970) in addition to the impact of general buyer characteristics, future research could focus on the behavior of individuals and teams within the buying center (e.g., by adapting a conceptual scheme for research on leadership effectiveness) or connect cognitive-behavioral aspects with the proposed framework (Ashour 1982). Third, interesting results could be obtained by connecting purchasing strategies with the analytical framework. A lack of coordination between the PO and supply strategies has been identified in prior research. As Nollet, Ponce, and Campbell (2005) noted, strategy research in supply management has a high potential for further development, especially when associated with organizational research questions. Similarly, this literature review could identify only three papers dealing with the relationship of strategy and structure in purchasing, wherefore we suggest future research could study how purchasing strategy influences the structure of purchasing and vice versa.

Finally, our analytical framework assumed that purchasing is performed in-house and did not take the outsourcing decision into consideration. Obviously, when deciding about how to organize purchasing, the question as to whether or not purchasing should be kept in-house also has to be answered. Thus, our analytical framework could be extended to consider the outsourcing decision for purchasing as well.

\subsection{Limitations of the research methodology}

Although the literature review paid attention to methodological rigor by applying a replicable and transparent selection process for relevant articles, the findings of the review may be mitigated by some limitations of the literature review method. First, the databases used in the search process (i.e. Business Source Premier and ABI/Inform Global) might not contain all journals that could be relevant for the review. Second, our restriction to academic journals excluded non-peer-reviewed journals, books and non-English publications, among others. Although our approach analyzes the most important journals 
in several management disciplines, it cannot be ruled out that relevant work has appeared elsewhere. In addition, we did not consider research that appeared in other literature streams or research fields, such as health case or medicine, and that may have implications for the organization of purchasing as well. Thus, it is clear that the selection criteria in terms of the keywords used and the journals and databases considered may have defined the sample in ways that other keywords or research procedures may not have (Newbert 2007). Thus, to extend the scope of this review, scholars could consider employing alternative selection methods or using alternative search engines, such as Google Scholar and Citations, Scopus or EconLit databases.

\subsection{Summary}

Research results discussed in this paper demonstrate that the PO is important for the competitive success of the purchasing department and the firm. The PO can have a significant impact on the competitive position and profitability of the company. As could be shown in this review, research on the organization of purchasing has concentrated on a broad variety of different topics and has established itself as an important stream in the area of purchasing research. However, many gaps became apparent in the existing literature, which need to be closed in future research to further our understanding of the functioning of POs. This literature review may assist researchers in finding interesting topics and provides anchors and directions for future research.

\section{Figure 6: Identified topics for future research on purchasing organization}

\begin{tabular}{|c|c|}
\hline Research fields & Research gaps and suggested areas for future research \\
\hline $\begin{array}{l}\text { Structural } \\
\text { characteristics } \\
\text { \& determinants }\end{array}$ & $\begin{array}{l}\text { 1) Analyze inconsistent results between contextual variables and the structure of the purchasing function. } \\
\text { 2) Study further contextual variables in purchasing research. } \\
\text { 3) Discuss the structure of the PO in light of its interaction with other functions. } \\
\text { 4) Identify additional contingency relationships to further our understanding of which situational factors influence } \\
\text { the PO. }\end{array}$ \\
\hline $\begin{array}{l}\text { Organizational } \\
\text { types (private) }\end{array}$ & $\begin{array}{l}\text { 1) Analyze the lead-buyer concept and shared service centers in more detail. } \\
\text { 2) Develop more comprehensive typologies of POs to differentiate alternative structural designs. } \\
\text { 3) Study how and why institutional structures in purchasing change over time. } \\
\text { 4) Address the change management process and related requirements. }\end{array}$ \\
\hline $\begin{array}{l}\text { Organizational } \\
\text { types (public) }\end{array}$ & $\begin{array}{l}\text { 1) Explain how the characteristics of the public purchasing function impact the structure of purchasing. } \\
\text { 2) Analyze patterns in the use of teams and the commodity management concept in public institutions. } \\
\text { 3) Focus on the impact of public procurement law on the structure of public purchasing. } \\
\text { 4) Study PO roles and responsibilities in large government buying organizations. }\end{array}$ \\
\hline $\begin{array}{l}\text { Performance } \\
\text { impact }\end{array}$ & $\begin{array}{l}\text { 1) Advance operationalization and measurement of organizational PP with respect to the dimensions of efficiency, } \\
\text { effectiveness and adaptiveness. } \\
\text { 2) Study the contingency relationships between strategic supply management and strategies and different POs and } \\
\text { financial performance of the firm. } \\
\text { 3) Focus on the impact of contextual variables on PP. } \\
\text { 4) Focus on the effect of the PO on the purchasing agent's performance. } \\
\text { 5) Explain the performance impact of POs in the public sector in the context of public-sector goals. }\end{array}$ \\
\hline $\begin{array}{l}\text { Theoretical } \\
\text { research }\end{array}$ & $\begin{array}{l}\text { 1) Study how alternative structural designs of the PO impact motivation and control systems in purchasing. } \\
\text { 2) Derive guidelines for the PO of multinational companies that help to decide where in the company network } \\
\text { purchasing authority for coordination should be located and that help to reduce system complexity. } \\
\text { 3) Investigate whether to outsource purchasing or to keep it in-house and how outsourcing of purchasing impacts } \\
\text { the competitive position of the company. } \\
\text { 4) Develop theoretical performance measures for POs. }\end{array}$ \\
\hline $\begin{array}{l}\text { Analytical } \\
\text { framework }\end{array}$ & $\begin{array}{l}\text { 1) Consider the influence of the organization on the environment. } \\
\text { 2) Analyze the organization of purchasing from a process-oriented perspective. } \\
\text { 3) Incorporate a reward/measurement component of buying behavior. } \\
\text { 4) Conceptualize the social structure of the buying center and connect cognitive-behavioral aspects. } \\
\text { 5) Connect purchasing strategies and study how selected strategies influence the PO. } \\
\text { 6) Include the outsourcing decision into the framework. }\end{array}$ \\
\hline
\end{tabular}




\section{Appendix A: Summary of search results by selection filters and criteria}

\begin{tabular}{|c|c|c|c|c|c|}
\hline Filter Type & \multicolumn{2}{|l|}{ Description and guidelines } & $\begin{array}{l}42 \text { pre-selected } \\
\text { journals results }\end{array}$ & $\begin{array}{l}\text { Business Source } \\
\text { Premier results }\end{array}$ & $\begin{array}{l}\text { ABI/Inform } \\
\text { Global results }\end{array}$ \\
\hline $\begin{array}{l}\text { Peer-reviewed jour- } \\
\text { nals }\end{array}$ & \multicolumn{5}{|c|}{$\begin{array}{l}\text { Search for articles that appeared in one of the } 42 \text { pre-selected journals, in the selected databases or in addi- } \\
\text { tional (peer-reviewed) journals that contained papers that were cited in one of the previously selected papers. }\end{array}$} \\
\hline \multirow{3}{*}{$\begin{array}{l}\text { Keyword search } \\
\text { 'title' }\end{array}$} & \multirow{3}{*}{$\begin{array}{l}\text { Ensure relevance by requiring } \\
\text { that all articles contain at } \\
\text { least one keyword/keyword } \\
\text { combination in their title. }\end{array}$} & Groups $\mathrm{A}+\mathrm{B}$ & 177 & 531 & 539 \\
\hline & & Group C & 49 & 144 & 112 \\
\hline & & Total & 226 & 675 & 651 \\
\hline \multirow{3}{*}{$\begin{array}{l}\text { Keyword search } \\
\text { 'abstract' }\end{array}$} & \multirow{3}{*}{$\begin{array}{l}\text { Ensure relevance by requiring } \\
\text { that all articles contain at } \\
\text { least one keyword/keyword } \\
\text { combination in their abstract. }\end{array}$} & Groups A+B & \multirow{6}{*}{$\begin{array}{l}\text { All } 226 \text { papers } \\
\text { were subjected to a a } \\
\text { manual analysis of } \\
\text { their abstracts } \\
\text { and, in case of } \\
\text { relevance, were } \\
\text { completely read to } \\
\text { examine their } \\
\text { content. }\end{array}$} & 13968 & 15326 \\
\hline & & Group C & & 1569 & 426 \\
\hline & & Total & & 15537 & 15752 \\
\hline \multirow{3}{*}{$\begin{array}{l}\text { Keyword search } \\
\text { 'title \& abstract' }\end{array}$} & \multirow{3}{*}{$\begin{array}{l}\text { Ensure relevance by requiring } \\
\text { that all articles contain at } \\
\text { least one keyword in their } \\
\text { title and abstract }\end{array}$} & Groups $A+B$ & & 371 & 365 \\
\hline & & Group C & & 102 & 63 \\
\hline & & Total & & 473 & 428 \\
\hline
\end{tabular}

1) Content analysis of the abstracts by conceptual framework guidelines

Results from the 42 pre-selected journals and the selected databases were consolidated and duplicate articles were eliminated.

Ensure relevance of content by requiring that abstracts of the selected articles focus organizational issues of purchasing.

Content analysis \&

Consolidation

\section{2) Content analysis of the entire text by conceptual framework guidelines}

Ensure relevance by reading all remaining articles in their entirety.

Articles focusing on 'supply chain management' or 'logistics' organization, 'behavioral or informal aspects' of purchasing organizations and process-oriented organization were excluded.

Ensure transparent assessment and classification by subjecting the selected articles to descriptive and thematic analysis according to the content categories of the analytical framework.

Intermediate results

Snowball approach
Ensure relevance by a snowball approach based on all previously selected articles.
$45^{1}$

\section{Sample size}

${ }_{1}$ We identified 45 articles that appeared in one of the 42 pre-selected journals and used at least one of the keywords/keyword combinations in the title.

${ }_{2}$ We identified 5 articles by searching the databases Business Source Premier and ABI/Inform Global. These articles used one of the keywords/keyword combinations in the title and abstract.

3 We identified 35 articles by a snowball approach. 29 out of 35 appeared in one of the 42 pre-selected journals and have not used one of the keywords/keyword combinations in the title. 6 out of 35 appeared others than the 42 pre- selected (but nevertheless peer-reviewed) journals and have not used one of the keywords/keyword combinations in the title. These articles were considered relevant and added to the content analysis. 


\section{Appendix B: Selected and reviewed journals}

\begin{tabular}{|c|c|}
\hline Journal & Number of articles \\
\hline $\begin{array}{l}\text { Management International Review; Journal of World Business; International Business Review; Journal } \\
\text { of International Business Studies; Journal of Business }\end{array}$ & al \\
\hline Journal of International Management & 1 \\
\hline Total (6 International Business Journals) & $\mathbf{1}$ \\
\hline Journal of Marketing Research; Journal of International Marketing & o \\
\hline International Journal of Research in Marketing & 1 \\
\hline International Marketing Review & 1 \\
\hline Journal of the Academy of Marketing Science & 1 \\
\hline Journal of Marketing Research & 1 \\
\hline Journal of Strategic Marketing & 1 \\
\hline European Journal of Marketing & 2 \\
\hline Journal of Business and Industrial Marketing & 2 \\
\hline Journal of Business Research & 4 \\
\hline Journal of Marketing & 5 \\
\hline Industrial Marketing Management & 9 \\
\hline Total (12 International Marketing Management Journals) & 27 \\
\hline $\begin{array}{l}\text { Supply Chain Management Review; International Journal of Operations and Production Management; } \\
\text { International Journal of Production Research; International Journal of Business Performance Manage- } \\
\text { ment }\end{array}$ & $;$ \\
\hline International Journal of Production Economics & 1 \\
\hline International Journal of Physical Distribution and Logistics Management & 1 \\
\hline Journal of Operations Management & 1 \\
\hline Omega - The International Journal of Management Science & 1 \\
\hline Supply Chain Management - An international Journal & 2 \\
\hline Journal of Purchasing and Supply Management ${ }^{2}$ & 14 \\
\hline Journal of Supply Chain Management - A Global Review of Purchasing and Supplyı & 24 \\
\hline Total (11 Operations and Supply (Chain) Management Journals & 44 \\
\hline $\begin{array}{l}\text { California Management Review; Organization Science; Administrative Science Quarterly; Academy of } \\
\text { Management Journal; Academy of Management Review; Sloan Management Review; Journal of Man- } \\
\text { agement Studies; Journal of Management; Strategic Management Journal; British Journal of Manage- } \\
\text { ment Academy of Management Perspectives } 3\end{array}$ & - \\
\hline Management Science & 1 \\
\hline Harvard Business Review & 1 \\
\hline Total (13 General Management Journals) & 2 \\
\hline Total (published in 42 selected Journals) & 74 \\
\hline Total (published in 8 other Journals4) & $\mathbf{1 1}$ \\
\hline Total (all articles published in 50 selected Journals) & 85 \\
\hline \multicolumn{2}{|c|}{$\begin{array}{l}\text { 'Before 1999, the Journal of Supply Chain Management (4) was named International Journal of Purchasing and Materials Manage- } \\
\text { ment (6), before } 1991 \text { Journal of Purchasing and Materials Management (6) and before } 1974 \text { Journal of Purchasing (7). } \\
{ }^{2} \text { Before } 2003 \text { the Journal of Purchasing and Supply Management (9) was known as the European Journal of Purchasing and Supply } \\
\text { Management (5). } \\
{ }^{3} \text { Academy of Management Perspectives was formerly known as Academy of Management Executive. } \\
4 \text { International Journal of Logistics: Research and Applications; Journal of Business Logistics; Journal of Public Budgeting, Accountin } \\
\text { and Financial Management; Journal of Public Procurement; Journal of Management Research; Service Industries Journal; Produc- } \\
\text { tion Planning and Control; International Journal of Procurement Management. }\end{array}$} \\
\hline
\end{tabular}




\section{Appendix C: List of identified and reviewed articles}

Arnold, Ulli (1999): Organization of Global Sourcing: Ways towards an Optimal Degree of Centralization, European Journal of Purchasing and Supply Management, 5 (3): 167-174.

Bacon, Paul A. (1971): Centralized-Decentralized Purchasing in the Academic Institution, Journal of Purchasing, 7 (3): 56-68.

Bakker, Elmer, Helen Walker, Fredo Schotanus, and Christine Harland (2008): Choosing an Organisational Form: The Case of Collaborative Procurement Initiatives, International Journal of Procurement Management, 1 (3): 297-317.

Belmonte, Robert M. (1972): Another Look at Large-Scale Intergovernmental Cooperative Purchasing, Journal of Purchasing, 8 (1): $34-49$.

Bloom, Harold and James M. Nardone (1984): Organizational Level of the Purchasing Function, Journal of Purchasing and Materials Management, 20 (2): 14-17.

Call, Rex V. (1968): Purchasing in the Academic Institution, Journal of Purchasing, 4 (2): 70-77.

Cavinato, Joseph L. (1992): Evolving Procurement Organizations: Logistics Implications, Journal of Business Logistics, 13 (1): 2745 .

Corey, E. Raymond (1978): Should Companies Centralize Procurement?, Harvard Business Review, 56 (6): 102-110.

Crow, Lowell E. and Jay D. Lindquist (1985): Impact of Organizational and Buyer Characteristics on the Buying Center, Industrial Marketing Management, 14 (1): 49-58.

David, Julie Smith., Yuhchang Hwang, Buck K. W. Pei, and J. Hal Reneau (2002): Performance Effects of Congruence Between Product Competitive Strategies and Purchasing Management Design, Management Science, 48 (7): 866-885.

Dawes, Philip L., Grahame R. Dowling, and Paul G. Patterson (1992): Factors Affecting the Structure of Buying Centers for the Purchase of Professional Advisory Services, International Journal of Research in Marketing, 9 (3): 269-279.

Doucette, William R. (1997): Influences on Member Commitment to Group Purchasing Organizations, Journal of Business Research, 40 (3): 183-189.

Englyst, Linda, Frances Jorgensen, John Johansen, and Ole S. Mikkelsen (2008): Commodity Team Motivation and Performance, Journal of Purchasing and Supply Management, 14 (1): $15-27$.

Essig, Michael (2000): Purchasing Consortia as Symbiotic Relationships: Developing the Concept of "Consortium Sourcing", European Journal of Purchasing and Supply Management, 6 (1): 13-22.

Farrer, Dean G. (1969): The Organization of a Military Procurement Function, Journal of Purchasing, 5 (1): 68-81.

Fearon, Harold E. (1988): Organizational Relationships in Purchasing, Journal of Purchasing and Materials Management, 24 (4): 2-12.

Fearon, Harold E. and Donald L. Ayres (1967): Effect Of Centralized Purchasing On Hospital Costs, Journal of Purchasing, 3 (3): 22-35.
Garrido-Samaniego, M. José and Jesús Gutiérrez-Cillán (2004): Determinants of Influence and Participation in the Buying Center: An Analysis of Spanish Industrial Companies, Journal of Business and Industrial Marketing, 19 (5): 320-336.

Germain, Richard and Cornelia Dröge (1997): Effects of Just-inTime Purchasing Relationships on Organizational Design, Purchasing Department Configuration, and Firm Performance, Industrial Marketing Management, 26 (2): 115-125.

Germain, Richard and Cornelia Dröge (1998): The Context, Organizational Design, and Performance of JIT Buying Versus NonJIT Buying Firms, International Journal of Purchasing and Materials Management, 34 (2): 12-18.

Gianakis, Gerasimos A. and Xiao Hu Wang (2000): Decentralization of the Purchasing Function in Municipal Government: A National Survey, Journal of Public Budgeting, Accounting and Financial Management, 12 (3): 421-440.

Giunipero, Larry C. and Robert M. Monczka (1990): Organizational Approaches to Managing International Sourcing, International Journal of Physical Distribution and Logistics Management, 20 (4): 3-12.

Goh, Mark and Geok-Theng Lau (1998): Electronics International Procurement Offices in Singapore, European Journal of Purchasing and Supply Management, 4 (2/3): 119-126.

Grønhaug, Kjell (1975): Autonomous vs. Joint Decisions in Organizational Buying, Industrial Marketing Management, 4 (5): 265271.

Grønhaug, Kjell (1976): Exploring Environmental Influences in Organizational Buying, Journal of Marketing Research, 13 (3): 225-229.

Hardwick, Clyde T. (1969): Regional Purchasing: A Study in Governmental Cooperative Buying, Journal of Purchasing, 5 (4): 13-19.

Hartmann, Evi, Gerhard Trautmann, and Christopher Jahns (2008): Organizational Design Implications of Global Sourcing: A Multiple Case Study Analysis on the Application of Control Mechanisms, Journal of Purchasing and Supply Management, 14 (1): 28-42.

Johnson, P. Fraser (1999): The Pattern of Evolution in Public Sector Purchasing Consortia, International Journal of Logistics: Research and Applications, 2 (1): 57-73.

Johnson, P. Fraser, Robert D. Klassen, Michiel R. Leenders, and Harold E. Fearon (2002): Determinants of Purchasing Team Usage in the Supply Chain, Journal of Operations Management, 20 (1): 77-89.

Johnson, P. Fraser and Michiel R. Leenders (2001): The Supply Organizational Structure Dilemma, Journal of Supply Chain Management, 37 (3): 4-11.

Johnson, P. Fraser and Michiel R. Leenders (2004): Implementing Organizational Change in Supply Towards Decentralization, Journal of Purchasing and Supply Management, 10 (4/5): 191200.

Johnson, Fraser P. and Michiel R. Leenders (2006): A Longitudinal Study of Supply Organizational Change, Journal of Purchasing and Supply Management, 12 (6): 332-342.

Johnson, P. Fraser, Michiel R. Leenders, and Harold E. Fearon (1998a): Evolving Roles and Responsibilities of Purchasing Or- 
ganizations, International Journal of Purchasing and Materials Management, 34 (1): 2-11.

Johnson, P. Fraser, Michiel R. Leenders, and Harold E. Fearon (1998b): The Influence of Organizational Factors on Purchasing Activities, International Journal of Purchasing and Materials Management, 34 (3): 10-19.

Johnson, P. Fraser, Michiel R. Leenders, and Harold E. Fearon (2006): Supply's Growing Status and Influence: A Sixteen-Year Perspective, Journal of Supply Chain Management, 42 (2): 3343.

Johnson, P. Fraser, Michiel R. Leenders, and Clifford P. McCue (2003): A Comparison of Purchasing's Organizational Roles and Responsibilities in the Public and Private Sector, Journal of Public Procurement, 3 (1): 57-74.

Johnston, Wesley J. and Thomas V. Bonoma (1981a): The Buying Center: Structure and Interaction Patterns, Journal of Marketing, 45 (3): 143-156.

Johnston, Wesley J. and Thomas V. Bonoma (1981b): Purchase Process for Capital Equipment and Services, Industrial Marketing Management, 10 (4): 253-264.

Juha, Munnuka and Järvi Pentti (2008): Managing Risks in Organizational Purchasing Through Adaptation of Buying Centre Structure and the Buying Process, Journal of Purchasing and Supply Management, 14 (4): 253-262.

Kamann, Dirk-Jan F. (2007): Organizational Design in Public Procurement: A Stakeholder Approach, Journal of Purchasing and Supply Management, 13 (2): 127-136.

Klebba, Joanne M. and F. Robert Dwyer (1981): Environmental Impact on Purchase Decision Structure, Journal of Purchasing and Materials Management, 17 (1): 30-36.

Kolchin, Michael G. (1986) The Role of Structure in the Performance of Department Store Purchasing Agents, Journal of Purchasing and Materials Management, 22 (1): 7-12.

Kotteaku, Adrianna G., Lambros G. Laios, and Socrates J. Moschuris (1995): The Influence of Product Complexity on the Purchasing Structure, Omega, 23 (1): 27-39.

Laing, Angus W., Seonaidh Cotton, Rita Joshi, Gordon Marnoch, Lorna McKee and John Reid (1998): The Buying Centre: Patterns of Structure and Interaction in Primary Health Care, Service Industries Journal, 18 (3): 20-37.

Laing, Angus W. and Seonaidh Cotton (1997): Patterns of InterOrganizational Purchasing: Evolution of Consortia-Based Purchasing Amongst GP Fundholders, European Journal of Purchasing and Supply Management, 3 (2): 83-91.

Laois, Lambros and Evangelos Xideas (1994a): An Empirical Investigation of Institutional and Industrial Purchasing Structure, European Journal of Marketing, 28 (4): 20-38.

Laois, Lambros and Evangelos Xideas (1994b): An Investigation into the Structure of the Purchasing Function of State-Controlled Enterprises, Journal of Business Research, 29 (1): 13-21.

Lau, Geok-Theng., Mark Goh, and Shan Lei Phua (1999): Purchase-Related Factors and Buying Center Structure: An Empirical Assessment, Industrial Marketing Management, 28 (6): 573-587.

Lewin, Jeffrey E. (2001): The Effects of Downsizing on Organizational Buying Behavior: An Empirical Investigation, Journal of the Academy of Marketing Science, 29 (2): 151-164.
Lewin, Jeffrey E. and Naveen Donthu (2005): The Influence of Purchase Situation on Buying Center Structure and Involvement: A Selected Meta-Analysis of Organizational Buying Behavior Research, Journal of Business Research, 58 (10): 1381-1390.

Lynn, Susan A. (1987): Identifying Buying Influences for a Professional Service: Implications for Marketing Efforts, Industrial Marketing Management, 16 (2): 119-130.

Mattson, Melvin R. (1988): How to Determine the Composition and Influence of a Buying Center, Industrial Marketing Management, 17 (3): 205-214.

McCabe, Donald L. (1987): Buying Group Structure: Constriction at the Top, Journal of Marketing, 51 (4): 89-98.

McCue, Clifford P. and Jack T. Pitzer (2000): Centralised vs. Decentralised Purchasing: Current Trends in Governmental Procurement Practices, Journal of Public Budgeting, Accounting \& Financial Management, 12 (3): 400-421.

McQuiston, Daniel H. (1989): Novelty, Complexity, and Importance as Causal Determinants of Industrial Buyer Behavior, Journal of Marketing, 53 (2): 66-79.

McWilliams, Robert D., Earl Naumann, and Stan Scott (1992): Determining Buying Center Size, Industrial Marketing Management, 21 (1): 43-49.

Naumann, Earl and John C. Kim (1986): A Macro Contingency Approach to the Study of Purchasing Behavior, Journal of Purchasing and Materials Management, 22 (3): 21-27.

Narasimhan, Ram and Joseph R. Carter (1990): Organisation, Communication and Coordination of International Sourcing, International Marketing Review, 7 (2): 6-20.

Nassimbeni, G. and M. Sartor (2006): International Purchasing Offices in China, Production Planning and Control, 17 (5): 494507.

Nellore, Rajesh and Jaideep Motwani (1999): Procurement Commodity Structures: Issues, Lessons and Contributions, European Journal of Purchasing and Supply Management, 5 (3/4): 157-166.

Nollet, Jean and Martin Beaulieu (2003): The Development of Group Purchasing: An Empirical Study in the Healthcare Sector, Journal of Purchasing and Supply Management, 9 (1): 3-10.

Nollet, Jean and Martin Beaulieu (2005): Should an Organisation Join a Purchasing Group?, Supply Chain Management, 10 (1): 1117 .

Pooley, John and Steven C. Dunn (1994): A Longitudinal Study of Purchasing Positions: 1960-1989, Journal of Business Logistics, 15(1): 193-214.

Quintens, Lieven, Paul Matthyssens, and Wouter Faes (2005): Purchasing Internationalisation on Both Sides of the Atlantic, Journal of Purchasing and Supply Management, 11 (2/3): 57-71.

Quintens, Lieven, Pieter Pauwels, and Paul Matthyssens (2006b): Global Purchasing Strategy: Conceptualization and Measurement, Industrial Marketing Management, 35 (7): 881-891.

Reck, Ross R. and Brian G. Long (1983): Organizing Purchasing as a Profit Center, Journal of Purchasing and Materials Management, 19 (4): 2-6.

Sanchez-Rodriguez, C., D. Hemsworth, A. R. Martınez-Lorente and S. G. Clavel (2006): An Empirical Study on the Impact of Standardization of Materials and Purchasing Procedures on 
Purchasing and Business Performance, Supply Chain Management: 11 (1): 56-64.

Schiele, Joseph J. (2005): Improving Organizational Effectiveness Through Meaningful Involvement of Municipal Purchasing Departments: Case studies from Ontario Canada, Journal of Public Procurement, 5 (2): 145-163.

Schotanus, Fredo and Jan Telgen (2007): Developing a Typology of Organisational Forms of Cooperative Purchasing, Journal of Purchasing and Supply Management, 13 (1): 53-68.

Spekman, Robert E. and Louis W. Stern (1979): Environmental Uncertainty and Buying Group Structure: An Empirical Investigation, Journal of Marketing, 43 (2): 54-64.

Stanley, Linda L. (1993): Linking Purchasing Department Structure and Performance: Toward a Contingency Model, Journal of Strategic Marketing, 1 (3): 211-219.

Steinhauer, Raleigh F. (1972): IGCP: The Wave of the Future?, Journal of Purchasing, 8 (3): 34-45.

Steinhauer, Raleigh F. (1976): Intergovernmental Cooperative Purchasing, Journal of Purchasing and Materials Management, 12 (1): 29-33.

Tella, Eija and Velli-Matti Virolainen (2005): Motives Behind Purchasing Consortia, International Journal of Production Economics, 93-94 (1): 161-168.

Thomas, Gloria P. and John F. Grashof (1982): Impact of Internal and External Environmental Stability on the Existence of Determinant Buying Rules, Journal of Business Research, 10 (2): 159168.

Tirimanne, D. N. and A. Ariyawardana (2008): Use of Organizational Design Features in Purchasing, Journal of Management Research, 8 (3): 162-167.
Trautmann, Gerhard, Lydia Bals, and Evi Hartmann (2009): Global Sourcing in Integrated Network Structures: The Case of Hybrid Purchasing Organizations, Journal of International Management, 15 (2): 194-208.

Trautmann, Gerhard, Virpi Turkulainen, Evi Hartmann, and Lydia Bals (2009): Integration in the Global Sourcing Organization: An Information Processing Perspective, Journal of Supply Chain Management, 45 (2): 57-74.

Trent, Robert J. (1996): Understanding and Evaluating CrossFunctional Sourcing Team Leadership, International Journal of Purchasing and Materials Management, 32 (4): 29-36.

Trent, Robert J. (1998): Individual and Collective Team Effort: A Vital Part of Sourcing Team Success, International Journal of Purchasing and Materials Management, 34 (4): 46-54.

Trent, Robert J. (2004): The Use of Organizational Design Features in Purchasing and Supply Management, Journal of Supply Chain Management, 40 (3): 4-18.

Trent, Robert J. and Robert M. Monczka (1994): Effective CrossFunctional Sourcing Teams: Critical Success Factors, International Journal of Purchasing and Materials Management, 30 (4): 3-11.

Webster, Frederick E. and Yoram Wind (1972): A General Model for Understanding Organizational Buying Behavior, Journal of Marketing, 36 (2): 12-19.

Wood, John (2005): Organizational Configuration as an Antecedent to Buying Centers' Size and Structure, Journal of Business and Industrial Marketing, 20 (6): 263-275.

Xideas, Evangelos and Socrates J. Moschuris (1998): The Influence of Product Type on the Purchasing Structure, European Journal of Marketing, 32 (11/12): 974-992.

\section{Appendix D: Number of articles on purchasing organization identified by year and selected journals}

\begin{tabular}{|c|c|c|c|c|c|c|c|c|c|c|}
\hline Journal & $\begin{array}{l}1967- \\
1970\end{array}$ & $\begin{array}{l}1971- \\
1975\end{array}$ & $\begin{array}{l}1976- \\
1980\end{array}$ & $\begin{array}{l}1981- \\
1985\end{array}$ & $\begin{array}{l}1986- \\
1990\end{array}$ & $\begin{array}{l}1991- \\
1995\end{array}$ & $\begin{array}{l}\text { 1996- } \\
2000\end{array}$ & $\begin{array}{l}\text { 2001- } \\
2005\end{array}$ & $\begin{array}{l}2006- \\
2009\end{array}$ & Total \\
\hline International Business Journals & & & & & & & & & & 1 \\
\hline Journal of International Management & & & & & & & & & 1 & 1 \\
\hline $\begin{array}{l}\text { International Marketing Management } \\
\text { Journals }\end{array}$ & & & & & & & & & & 27 \\
\hline $\begin{array}{l}\text { International Journal of Research in Market- } \\
\text { ing }\end{array}$ & & & & & & 1 & & & & 1 \\
\hline International Marketing Review & & & & & 1 & & & & & 1 \\
\hline $\begin{array}{l}\text { Journal of the Academy of Marketing Sci- } \\
\text { ence }\end{array}$ & & & & & & & & 1 & & 1 \\
\hline Journal of Marketing Research & & & 1 & & & & & & & 1 \\
\hline Journal of Strategic Marketing & & & & & & 1 & & & & 1 \\
\hline European Journal of Marketing & & & & & & 1 & 1 & & & 2 \\
\hline $\begin{array}{l}\text { Journal of Business and Industrial Market- } \\
\text { ing }\end{array}$ & & & & & & & & 2 & & 2 \\
\hline Journal of Business Research & & & & 1 & & 1 & 1 & 1 & & 4 \\
\hline Journal of Marketing & & 1 & 1 & 1 & 2 & & & & & 5 \\
\hline
\end{tabular}




\section{Appendix D continued: Number of articles on purchasing organization identified by year and selected journals}

\begin{tabular}{|c|c|c|c|c|c|c|c|c|c|c|}
\hline Journal & $\begin{array}{l}1967- \\
1970\end{array}$ & $\begin{array}{l}1971- \\
1975\end{array}$ & $\begin{array}{l}1976- \\
1980\end{array}$ & $\begin{array}{l}1981- \\
1985\end{array}$ & $\begin{array}{l}1986- \\
1990\end{array}$ & $\begin{array}{l}1991- \\
1995\end{array}$ & $\begin{array}{l}\text { 1996- } \\
2000\end{array}$ & $\begin{array}{l}2001- \\
2005\end{array}$ & $\begin{array}{l}\text { 2006- } \\
2009\end{array}$ & Total \\
\hline Industrial Marketing Management & & 1 & & 2 & 2 & 1 & 2 & & 1 & 9 \\
\hline $\begin{array}{l}\text { Operations and Supply (Chain) Man- } \\
\text { agement Journals }\end{array}$ & & & & & & & & & & 44 \\
\hline $\begin{array}{l}\text { International Journal of Production Eco- } \\
\text { nomics }\end{array}$ & & & & & & & & 1 & & 1 \\
\hline $\begin{array}{l}\text { International Journal of Physical Distribu- } \\
\text { tion and Logistics Management }\end{array}$ & & & & & 1 & & & & & 1 \\
\hline $\begin{array}{l}\text { Supply Chain Management - An interna- } \\
\text { tional Journal }\end{array}$ & & & & & & & & 1 & 1 & 2 \\
\hline Journal of Operations Management & & & & & & & & 1 & & 1 \\
\hline $\begin{array}{l}\text { Omega - The International Journal of Man- } \\
\text { agement Science }\end{array}$ & & & & & & 1 & & & & 1 \\
\hline $\begin{array}{l}\text { Journal of Purchasing and Supply Manage- } \\
\text { ment }\end{array}$ & & & & & & & 5 & 3 & 6 & 14 \\
\hline Journal of Supply Chain Management & 4 & 3 & 1 & 3 & 3 & 1 & 5 & 2 & 2 & 24 \\
\hline General Management Journals & & & & & & & & & & 2 \\
\hline Management Science & & & & & & & & 1 & & 1 \\
\hline Harvard Business Review & & & 1 & & & & & & & 1 \\
\hline 8 other Journals & & & & & & 2 & 4 & 2 & 3 & 11 \\
\hline Total (all articles) & 4 & 5 & 4 & 7 & 9 & 9 & 18 & 15 & 15 & 85 \\
\hline
\end{tabular}

\section{Appendix E: Number of articles on purchasing organization by year}

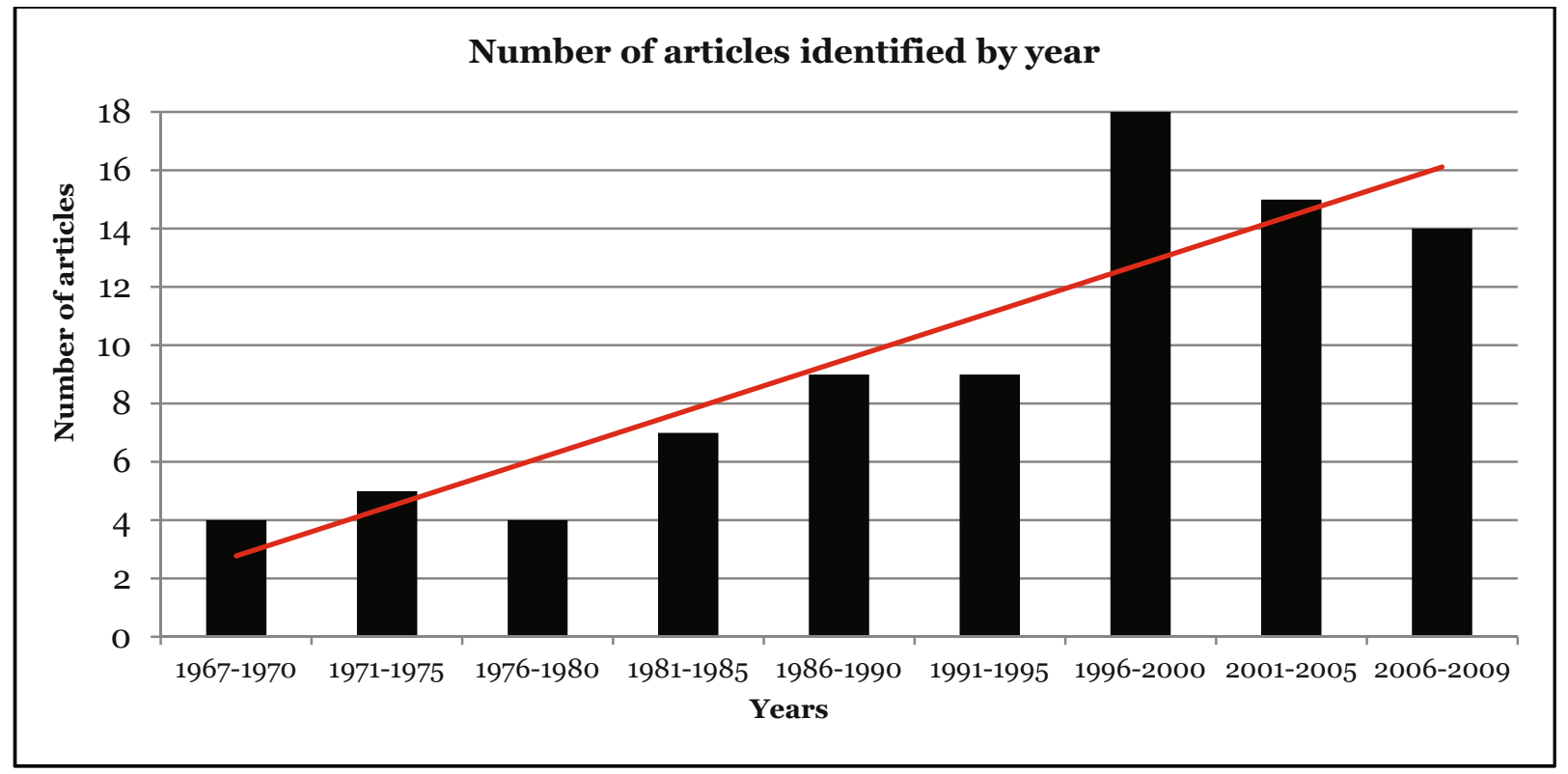




\section{Appendix F: Methodical approaches by number of articles and year}

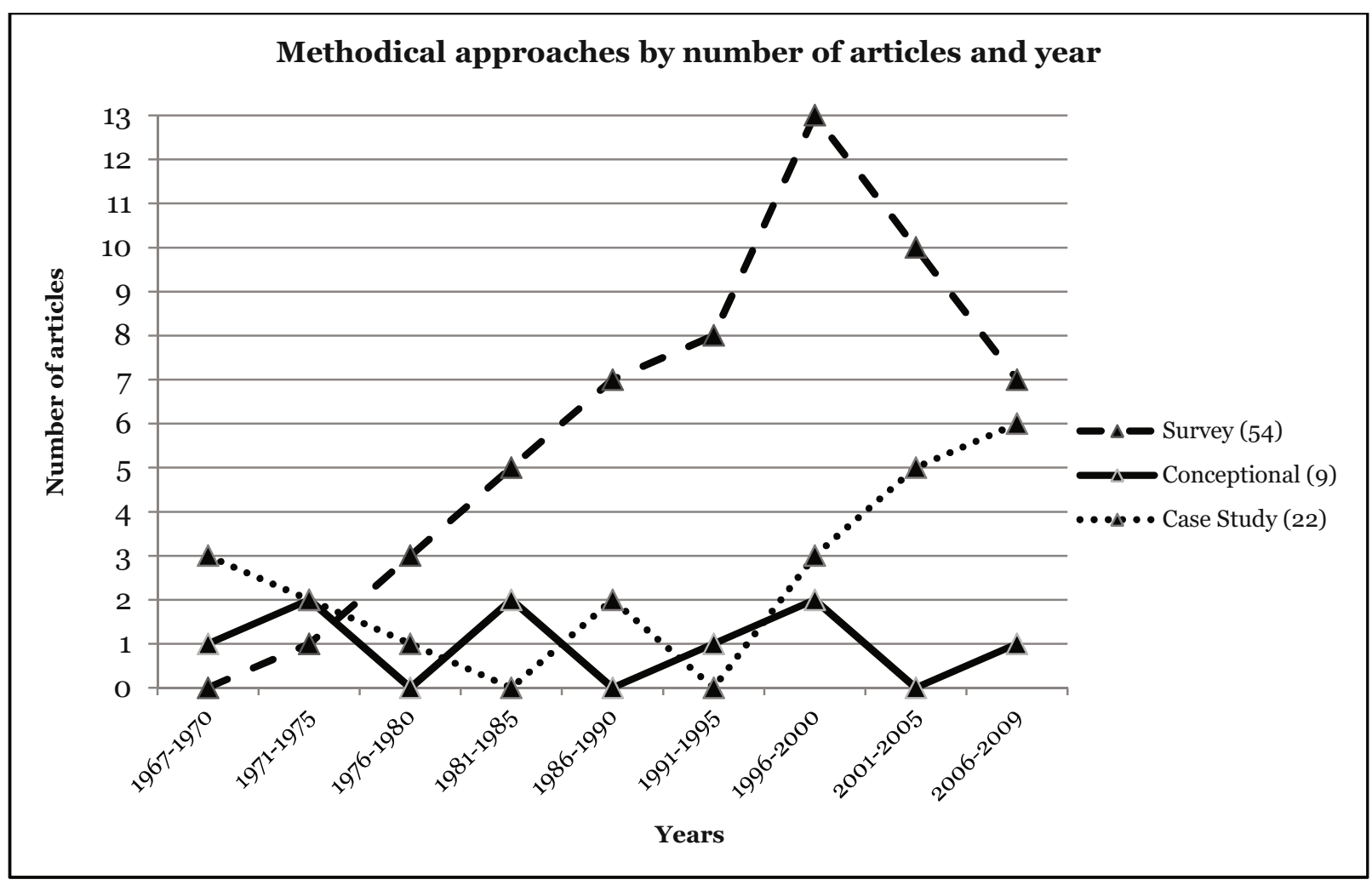

Appendix G: Components of the analytical framework by number of articles and year

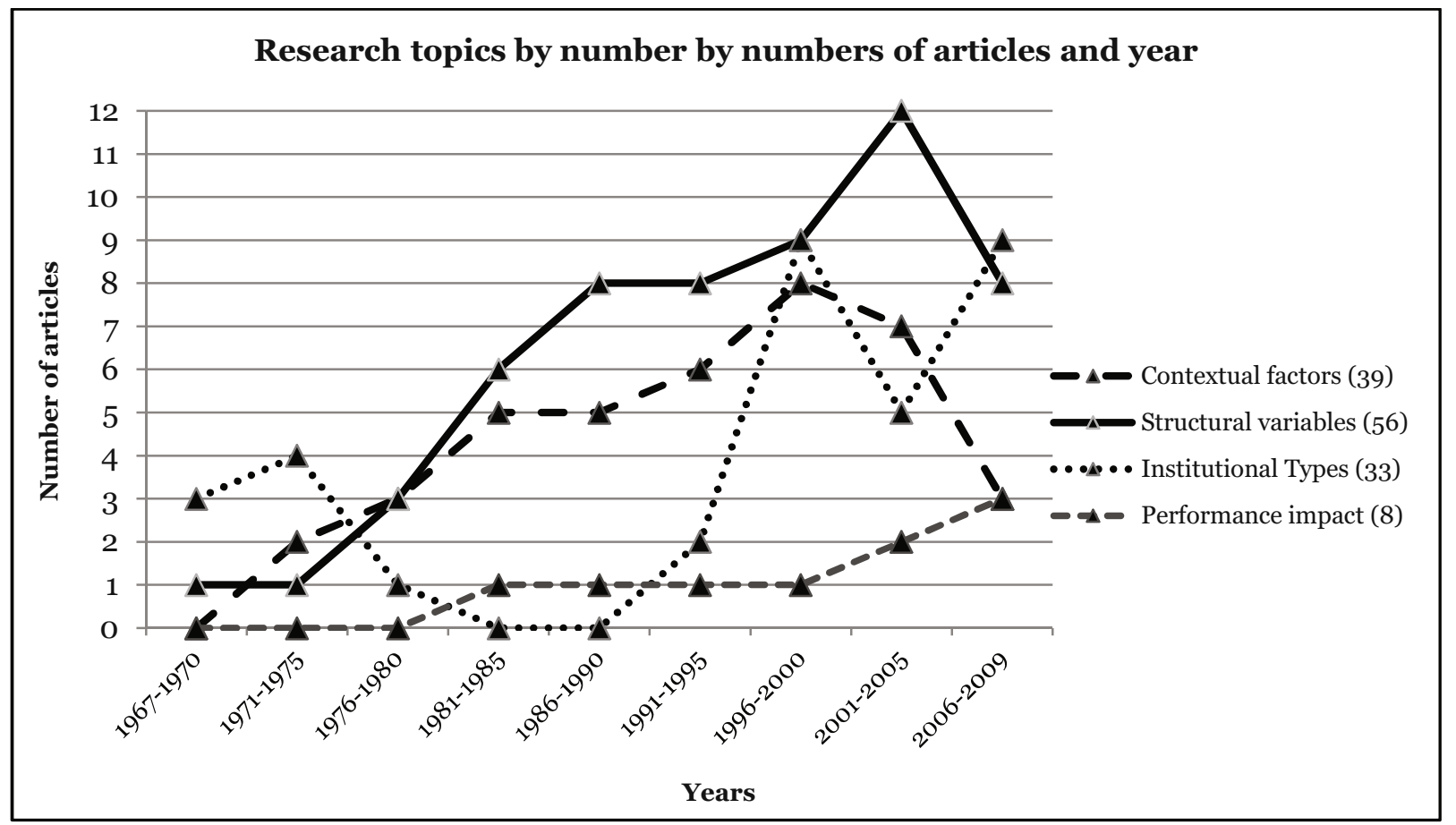




\section{Appendix H: Classification and taxonomy matrix (methodology vs. topic)}

\begin{tabular}{|c|c|c|c|c|c|c|c|}
\hline & Meth & ology & & Topic & & & \\
\hline Author (s) & $\begin{array}{l}\text { Sur- } \\
\text { vey }\end{array}$ & $\begin{array}{l}\text { Concep- } \\
\text { tional }\end{array}$ & $\begin{array}{l}\text { Case } \\
\text { study }\end{array}$ & $\begin{array}{l}\text { Contextu- } \\
\text { al factors }\end{array}$ & $\begin{array}{l}\text { Structural } \\
\text { variables }\end{array}$ & $\begin{array}{l}\text { Institutional } \\
\text { types }\end{array}$ & $\begin{array}{l}\text { Performance } \\
\text { impact }\end{array}$ \\
\hline Arnold (1999) & & & $\mathrm{X}_{\mathrm{C}}$ & & $\mathrm{Ce}$ & TYP & \\
\hline Bacon (1971) & & $\mathrm{X}$ & & & & $\mathrm{CM}$ & \\
\hline $\begin{array}{l}\text { Bakker, Walker, Scho- } \\
\text { tanus, and Harland (2008) }\end{array}$ & $\mathrm{X}_{\mathrm{C}}$ & & & & & IGCP & \\
\hline Belmonte (1972) & & & $\mathrm{X}$ & & & IGCP & \\
\hline $\begin{array}{l}\text { Bloom and Nardone } \\
\text { (1984) }\end{array}$ & & $\mathrm{X}$ & & & Co & & \\
\hline Call (1968) & & $\mathrm{X}$ & & & & $\mathrm{CM}$ & \\
\hline Cavinato (1992) & $\mathrm{X}$ & & & & $\mathrm{CeCo}$ & TYP & \\
\hline Corey (1978) & & & $\mathrm{X}$ & $\mathrm{PcOc}$ & $\mathrm{Ce}$ & & \\
\hline Crow and Lindquist (1985) & $\mathrm{X}$ & & & OcPcPsEf & $\mathrm{In}_{\mathrm{S}}$ & & \\
\hline $\begin{array}{l}\text { David, Hwang, Pei, and } \\
\text { Reneau (2002) }\end{array}$ & $\mathrm{X}$ & & & & $\mathrm{Ce}$ & & $\mathrm{Pi}$ \\
\hline $\begin{array}{l}\text { Dawes, Dowling, and } \\
\text { Patterson (1992) }\end{array}$ & $\mathrm{X}$ & & & OcPcPs & $\mathrm{In}_{\mathrm{S}}$ & & \\
\hline Doucette (1997) & $\mathrm{X}$ & & & & & IGCP & \\
\hline $\begin{array}{l}\text { Englyst, Jorgensen, Jo- } \\
\text { hansen, and Mikkelsen } \\
\text { (2008) }\end{array}$ & & & $\mathrm{X}$ & & & $\mathrm{CM}$ & \\
\hline Essig (2000) & $\mathrm{X}_{\mathrm{C}}$ & & & & & CS IGCP & $\mathrm{Pi}$ \\
\hline Farrer (1969) & & & $\mathrm{X}$ & & & TYP & \\
\hline Fearon (1988) & $\mathrm{X}$ & & & & CeCo & & \\
\hline Fearon and Ayres (1967) & & & $\mathrm{X}$ & & $\mathrm{Ce}$ & IGCP & \\
\hline $\begin{array}{l}\text { Garrido-Samaniego and } \\
\text { Gutiérrez-Cillán (2004) }\end{array}$ & $\mathrm{X}$ & & & OcPcPs & $\mathrm{StSpCeCoIn}$ Fo & & \\
\hline Germain and Dröge (1998) & $\mathrm{X}$ & & & Oc & Fo & & \\
\hline Germain and Dröge (1997) & $\mathrm{X}$ & & & Oc & Fo & & \\
\hline $\begin{array}{l}\text { Gianakis and Wang } \\
\text { (2000) }\end{array}$ & $\mathrm{X}$ & & & OcEf & $\mathrm{Ce}$ & & \\
\hline $\begin{array}{l}\text { Giunipero and Monczka } \\
\text { (1990) }\end{array}$ & & & $\mathrm{X}$ & & CeCo & & \\
\hline Goh and Lau (1998) & $\mathrm{X}$ & & & & & IPO & \\
\hline
\end{tabular}




\section{Appendix $H$ continued: Classification and taxonomy matrix (methodology vs. topic)}

\begin{tabular}{|c|c|c|c|c|c|c|c|}
\hline & Meth & ology & & Topic & & & \\
\hline Author (s) & $\begin{array}{l}\text { Sur- } \\
\text { vey }\end{array}$ & $\begin{array}{l}\text { Concep- } \\
\text { tional }\end{array}$ & $\begin{array}{l}\text { Case } \\
\text { study }\end{array}$ & $\begin{array}{l}\text { Contextu- } \\
\text { al factors }\end{array}$ & $\begin{array}{l}\text { Structural } \\
\text { variables }\end{array}$ & $\begin{array}{l}\text { Institutional } \\
\text { types }\end{array}$ & $\begin{array}{l}\text { Performance } \\
\text { impact }\end{array}$ \\
\hline Grønhaug (1976) & $\mathrm{X}$ & & & OcEf & In & & \\
\hline Grønhaug (1975) & $\mathrm{X}$ & & & OcPcPs & $\mathrm{In}_{\mathrm{S}}$ & ST & \\
\hline Hardwick (1969) & & & $\mathrm{X}$ & & & IGCP & \\
\hline $\begin{array}{l}\text { Hartmann, Trautmann, } \\
\text { and Jahns (2008) }\end{array}$ & & & $\mathrm{X}_{\mathrm{C}}$ & & CeFo & TYP & \\
\hline $\begin{array}{l}\text { Johnson, Leenders, and } \\
\text { Fearon (1998b) }\end{array}$ & $\mathrm{X}$ & & & OcEf PSCV & $\mathrm{CeCo}$ & & \\
\hline $\begin{array}{l}\text { Johnson, Leenders, and } \\
\text { Fearon (1998a) }\end{array}$ & $\mathrm{X}$ & & & Ef & $\mathrm{CeCo}$ & & \\
\hline Johnson (1999) & & & $\mathrm{X}$ & & & IGCP & \\
\hline $\begin{array}{l}\text { Johnson and Leenders } \\
\text { (2001) }\end{array}$ & & & $\mathrm{X}$ & & $\mathrm{Ce}$ & & \\
\hline $\begin{array}{l}\text { Johnson, Klassen, } \\
\text { Leenders, and Fearon } \\
\text { (2002) }\end{array}$ & $\mathrm{X}$ & & & Ef PSCV & $\mathrm{Ce}$ & ST & \\
\hline $\begin{array}{l}\text { Johnson, Leenders, and } \\
\text { McCue (2003) }\end{array}$ & $\mathrm{X}$ & & & & $\mathrm{Ce}$ & ST & \\
\hline $\begin{array}{l}\text { Johnson and Leenders } \\
\text { (2004) }\end{array}$ & & & $\mathrm{X}$ & & $\mathrm{Ce}$ & & \\
\hline $\begin{array}{l}\text { Johnson and Leenders } \\
\text { (2006) }\end{array}$ & $\mathrm{X}$ & & & & CeCo & ST & \\
\hline $\begin{array}{l}\text { Johnson, Leenders, and } \\
\text { Fearon (2006) }\end{array}$ & $\mathrm{X}$ & & & & $\mathrm{CeCo}$ & & \\
\hline $\begin{array}{l}\text { Johnston and Bonoma } \\
\text { (1981 a) }\end{array}$ & $\mathrm{X}$ & & & OcPcPs & $\mathrm{In}_{\mathrm{S}} \mathrm{Co}$ & & \\
\hline $\begin{array}{l}\text { Johnston and Bonoma } \\
\text { (1981 b) }\end{array}$ & $\mathrm{X}$ & & & OcPcPs & $\mathrm{In}_{\mathrm{S}}$ & & \\
\hline Juha and Pentti (2008) & $\mathrm{X}$ & & & PsEf & $\mathrm{SpCeIn}_{\mathrm{S}} \mathrm{Fo}$ & & \\
\hline Kamann (2007) & & $\mathrm{X}$ & & & & TYP & \\
\hline Klebba and Dwyer (1981) & $\mathrm{X}$ & & & Ef & SpCeFo & & \\
\hline Kolchin (1986) & $\mathrm{X}$ & & & & Fo & & $\mathrm{Pi}$ \\
\hline $\begin{array}{l}\text { Kotteaku, Laios, and Mos- } \\
\text { churis (1995) }\end{array}$ & $\mathrm{X}$ & & & $\mathrm{Pc}$ & CeFo Csv & & \\
\hline Laios and Xideas (1994 a) & $\mathrm{X}$ & & & PsEf & $\mathrm{Ce}$ Csv & & \\
\hline Laios and Xideas (1994 b) & $\mathrm{X}$ & & & PcPs & CeFo Csv & & \\
\hline
\end{tabular}




\section{Appendix $H$ continued: Classification and taxonomy matrix (methodology vs. topic)}

\begin{tabular}{|c|c|c|c|c|c|c|c|}
\hline & Meth & ology & & Topic & & & \\
\hline Author (s) & $\begin{array}{l}\text { Sur- } \\
\text { vey }\end{array}$ & $\begin{array}{l}\text { Concep- } \\
\text { tional }\end{array}$ & $\begin{array}{l}\text { Case } \\
\text { study }\end{array}$ & $\begin{array}{l}\text { Contextu- } \\
\text { al factors }\end{array}$ & $\begin{array}{l}\text { Structural } \\
\text { variables }\end{array}$ & $\begin{array}{l}\text { Institutional } \\
\text { types }\end{array}$ & $\begin{array}{l}\text { Performance } \\
\text { impact }\end{array}$ \\
\hline $\begin{array}{l}\text { Laing, Cotton, Joshi, Mar- } \\
\text { noch, McKee, and Reid } \\
\text { (1998) }\end{array}$ & $\mathrm{X}$ & & & Oc & In & & \\
\hline Laing and Cotton (1997) & $\mathrm{X}$ & & & & & IGCP & \\
\hline Lau, Goh, and Phua (1999) & $\mathrm{X}$ & & & PcPsEf & SpCeFo & & \\
\hline Lewin and Donthu (2005) & $\mathrm{X}_{\mathrm{C}}$ & & & $(\mathrm{PsPcEf})^{\mathbf{1}}$ & $\mathrm{CeIn}_{\mathrm{S}} \mathrm{Fo}^{*}$ & & \\
\hline Lewin (2001) & $\mathrm{X}$ & & & Oc & $\mathrm{CeIn}_{\mathrm{S}} \mathrm{Fo}$ & & \\
\hline Lynn (1987) & $\mathrm{X}$ & & & OcPcPs & $\mathrm{In}_{\mathrm{S}}$ & & \\
\hline Mattson (1988) & $\mathrm{X}_{\mathrm{C}}$ & & & $\mathrm{OcPc}$ & In & & \\
\hline McCabe (1987) & $\mathrm{X}$ & & & PcEf & $\mathrm{CeIn}_{\mathrm{S}} \mathrm{Fo}$ & & \\
\hline McCue and Pitzer (2000) & $\mathrm{X}$ & & & & $\mathrm{Ce}$ & & \\
\hline McQuiston (1989) & $\mathrm{X}$ & & & Ps & & & \\
\hline $\begin{array}{l}\text { McWilliams, Naumann, } \\
\text { and Scott (1992) }\end{array}$ & $\mathrm{X}$ & & & Ps & $\mathrm{In}_{\mathrm{S}}$ & & \\
\hline $\begin{array}{l}\text { Narasimhan and Carter } \\
\text { (1990) }\end{array}$ & & & $\mathrm{X}$ & & Co & & \\
\hline $\begin{array}{l}\text { Nassimbeni and Sartor } \\
\text { (2006) }\end{array}$ & & & $\mathrm{X}$ & & & IPO & \\
\hline Naumann and Kim (1986) & $\mathrm{X}$ & & & Pc PSCV & CeFo & & \\
\hline $\begin{array}{l}\text { Nellore and Motwani } \\
\text { (1999) }\end{array}$ & & & $\mathrm{X}_{\mathrm{C}}$ & & & $\mathrm{CM}$ & \\
\hline $\begin{array}{l}\text { Nollet and Beaulieu } \\
(2005)\end{array}$ & $\mathrm{X}_{\mathrm{C}}$ & & & & & IGCP & \\
\hline $\begin{array}{l}\text { Nollet and Beaulieu } \\
(2003)\end{array}$ & $\mathrm{X}_{\mathrm{C}}$ & & & & & IGCP & \\
\hline Pooley and Dunn (1994) & $\mathrm{X}$ & & & & Co & & \\
\hline $\begin{array}{l}\text { Quintens, Pauwels, and } \\
\text { Matthyssens (2006b) }\end{array}$ & $\mathrm{X}_{\mathrm{C}}$ & & & & StCe Csv & & \\
\hline $\begin{array}{l}\text { Quintens, Matthyssens, } \\
\text { and Faes (2005) }\end{array}$ & & & $\mathrm{X}$ & Ef & & & \\
\hline Reck and Long (1983) & & $\mathrm{X}$ & & & & & $\mathrm{Pi}$ \\
\hline $\begin{array}{l}\text { Sanchez-Rodriguez, } \\
\text { Hemsworth, Martinez- } \\
\text { Lorente, and Clavel (2006) }\end{array}$ & $\mathrm{X}$ & & & & St & & $\mathrm{Pi}$ \\
\hline $\begin{array}{l}\text { Schotanus and Telgen } \\
(2007)\end{array}$ & & & $\mathrm{X}_{\mathrm{C}}$ & & & TYP CS & \\
\hline
\end{tabular}




\section{Appendix $H$ continued: Classification and taxonomy matrix (methodology vs. topic)}

\begin{tabular}{|c|c|c|c|c|c|c|c|}
\hline & Meth & ology & & Topic & & & \\
\hline Author (s) & $\begin{array}{l}\text { Sur- } \\
\text { vey }\end{array}$ & $\begin{array}{l}\text { Concep- } \\
\text { tional }\end{array}$ & $\begin{array}{l}\text { Case } \\
\text { study }\end{array}$ & $\begin{array}{l}\text { Contextu- } \\
\text { al factors }\end{array}$ & $\begin{array}{l}\text { Structural } \\
\text { variables }\end{array}$ & $\begin{array}{l}\text { Institutional } \\
\text { types }\end{array}$ & $\begin{array}{l}\text { Performance } \\
\text { impact }\end{array}$ \\
\hline Schiele (2005) & & & $\mathrm{X}$ & & In & & \\
\hline Spekman and Stern (1979) & $\mathrm{X}$ & & & Ef & $\mathrm{SpCeIn}_{\mathrm{S}} \mathrm{Fo}$ & & \\
\hline Steinhauer (1972) & & & $\mathrm{X}$ & & & IGCP & \\
\hline Steinhauer (1976) & $\mathrm{X}$ & & & & & IGCP & \\
\hline Stanley (1993) & & $\mathrm{X}$ & & Oc & $\mathrm{CeFo}$ & & $\mathrm{Pi}$ \\
\hline $\begin{array}{l}\text { Tella and Virolainen } \\
\text { (2005) }\end{array}$ & & & $\mathrm{X}$ & & & $\mathrm{CS}$ & \\
\hline $\begin{array}{l}\text { Thomas and Grashof } \\
\text { (1982) }\end{array}$ & $\mathrm{X}$ & & & Ef & Fo & & \\
\hline $\begin{array}{l}\text { Tirimanne and Ariya- } \\
\text { wardana (2008) }\end{array}$ & $\mathrm{X}$ & & & & & & $\mathrm{Pi}$ \\
\hline $\begin{array}{l}\text { Trautmann, Turkulainen, } \\
\text { Hartmann, and Bals (2009) }\end{array}$ & & & $\mathrm{X}$ & $\mathrm{Pc}$ & StFo & $\mathrm{CM}$ & \\
\hline $\begin{array}{l}\text { Trautmann, Bals, and } \\
\text { Hartmann (2009) }\end{array}$ & & & $\mathrm{X}$ & $\mathrm{Pc}$ & $\mathrm{Ce}$ & $\mathrm{CM}$ & \\
\hline Trent (2004) & $\mathrm{X}$ & & & Oc & Co & & $\mathrm{Pi}$ \\
\hline Trent (1996) & & $\mathrm{X}$ & & & & ST & \\
\hline Trent (1998) & & $\mathrm{X}$ & & & & ST & \\
\hline Trent and Monczka (1994) & $\mathrm{X}_{\mathrm{C}}$ & & & & & ST & \\
\hline Webster and Wind (1972) & & $\mathrm{X}$ & & PSCV & & & \\
\hline Wood (2005) & $\mathrm{X}$ & & & Oc & $\mathrm{CeIn}_{\mathrm{S}} \mathrm{Fo}$ & & \\
\hline $\begin{array}{l}\text { Xideas and Moschuris } \\
\text { (1998) }\end{array}$ & $\mathrm{X}$ & & & $\mathrm{Pc}$ & CeFo Csv & & \\
\hline Total & 54 & 9 & 22 & 39 & 56 & 33 & 8 \\
\hline
\end{tabular}

$\mathbf{X}_{\mathbf{c}}$ : Hybrid papers with conceptual components assigned to the survey or the case study category.

Contextual factors

Oc: Organization characteristics

(19)

Pc: Product characteristics (18)

Ps: Purchase situation (13)

Ef: Environmental factors (14)

PSCV: Purchasing structure as a

contextual variable (4)

1 Meta-Analysis on contextual variables $\underline{\text { Structural variables }}$

Ce: (De-)Centralization (35)

Fo: Formalization (20)

In: Involvement (4)

$\mathrm{In}_{\mathrm{S}}$ : Size of buying center as Involve-

ment (14)

Co: Configuration (13)

Sp: Specialization (5)

St: Standardization (4)

Csv: Combined structural variables (5)
Institutional types

TYP: Typology (6)

IPO: International Procurement Office

(2)

ST: Sourcing teams (7)

CM: Commodity management (6)

CS: Cooperative sourcing (3)

IGCP: Intergovernmental cooperative purchasing (12)
Performance

Pi: Performance impact 


\section{Appendix I: Use of theory concepts in research on purchasing organizations}

Theory

Contribution
Bakker,

Walker,

$\begin{array}{llllll}\text { Schotanus, } & X & X & X & X\end{array}$

and Harland

(2008)
The four theoretical perspectives (TCT, RBV, CT, PAT) are used to assess the suitability of alternative organizational forms of collaborative procurement. A theoretical framework is presented which helps selecting an appropriate organizational form. 'Virtual networks' and 'Third-party organizations' as a form of collaborative procurement as well as 'Variants of the main forms' are discussed and analyzed according to the theoretical framework.
David,

Hwang, Pei, and Reneau $\mathrm{X}$

(2002)
CT is used to explore the contingency relationships among the following variables after controlling for environmental effects: (1) characteristics of product competitive strategies (cost leadership vs. differentiation), (2) characteristics of PO practices (degree of decentralization and span of coordination), (3) operational efficiency of the $\mathrm{PO}$ and (4) overall firm financial performance (ROA)
Hartmann,

Trautmann, and Jahns $\mathrm{X}$ (2008)
Considering ICT and CT, explanations for the application of different control mechanisms in the global sourcing context are derived and organizational design implications of global sourcing are discussed.

Naumann
$(1986)$$\quad \mathrm{X} \quad \mathrm{X}$
Matthyssens, and Faes $\mathrm{X}$
A macro-level analysis of CT and OST is applied that considers the interaction between the various systems and subsystems of purchasing, while a micro level analysis investigates the organizational (buying) behavior. The relationships between a macro contingency factor (technology) and two dimensions of organization structure (centralization and formalization) are studied.
The theoretical construct 'Global Purchasing strategy' is conceptualized in the RBV. GPS encompasses the organizational dimensions 'configuration of the global purchasing process', 'standardization of the global purchasing process', 'standardization of product-related characteristics' and 'standardization of the purchasing staff organization'.
Stanley

(1993)
$\mathrm{X}$

\section{$\mathrm{X}$}

CT and OST are used to develop a contingency framework to further our understanding of the environment-structureperformance relationship in purchasing. The framework considers that different types of organizational structures perform differently under different environmental conditions and assumes that efficiency, effectiveness and adaptiveness are influenced by variability, complexity and illiberality. 


\section{Appendix I continued: Use of theory concepts in research on purchasing organizations}

\begin{tabular}{|c|c|c|c|c|c|c|c|c|c|}
\hline & \multicolumn{8}{|c|}{ Theory } & \multirow[t]{2}{*}{ Contribution } \\
\hline Author(s) & 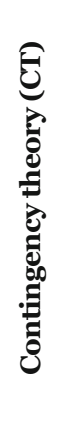 & 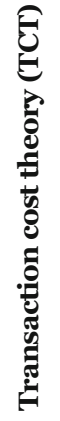 & 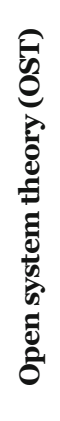 & 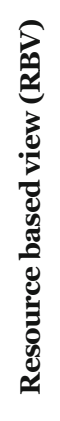 & 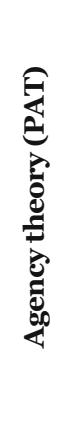 & 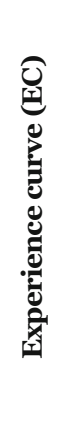 & 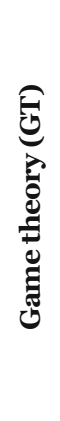 & 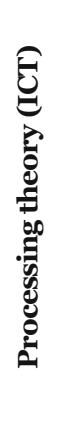 & \\
\hline $\begin{array}{l}\text { Tella and } \\
\text { Virolainen } \\
\text { (2005) }\end{array}$ & & $\mathrm{X}$ & & & & $\mathrm{X}$ & $\mathrm{X}$ & & $\begin{array}{l}\text { The motives behind purchasing consortia are analyzed from the } \\
\text { perspective of TCT, EC and GT, and are summarized to be the } \\
\text { following: (1) TCT: Reduction of transaction costs, (2) EC: Reduc- } \\
\text { tion of the material item costs, and (3) GT: Emphasis of trust } \\
\text { between consortium members and the profitability of coopera- } \\
\text { tion in the long run. }\end{array}$ \\
\hline $\begin{array}{l}\text { Trautmann, } \\
\text { Bals, and } \\
\text { Hartmann } \\
\text { (2009) }\end{array}$ & & $\mathrm{X}$ & & & & & & $\mathrm{X}$ & $\begin{array}{l}\text { TCT and ICT are used to develop a theoretically grounded pur- } \\
\text { chasing portfolio model to provide a comprehensive view of rele- } \\
\text { vant global synergy dimensions. TCT and ICP address the catego- } \\
\text { ry selection criteria for exploiting economies of scale, for econo- } \\
\text { mies of information and learning and economies of process. }\end{array}$ \\
\hline
\end{tabular}

\section{Acknowledgements}

The authors thank the department editor and three anonymous referees for their valuable comments and suggestions which helped to improve the paper considerably.

\section{References}

Anderson, Paul F. and Terry M. Chambers (1985): A Reward/Measurement Model of Organizational Buying Behavior, Journal of Marketing, 49 (2): 7-23.

Arnold, Ulli (1999): Organization of Global Sourcing: Ways towards an Optimal Degree of Centralization, European Journal of Purchasing and Supply Management, 5 (3): 167-174.

Ashour, Ahmed S. (1982): A Framework of a Cognitive-Behavioral Theory of Leader Influence and Effectiveness, Organizational Behavior and Human Performance, 30 (3): 407-430.

Bacon, Paul A. (1971): Centralized-Decentralized Purchasing in the Academic Institution, Journal of Purchasing, 7 (3): 56-68.

Baier, Christian, Evi Hartmann, and Roger Moser (2008): Strategic Alignment and Purchasing Efficacy: An Exploratory Analysis of Their Impact on Financial Performance, Journal of Supply Chain Management, 44 (4): 36-52.
Bakker, Elmer, Helen Walker, Fredo Schotanus, and Christine Harland (2008): Choosing an Organisational Form: The Case of Collaborative Procurement Initiatives, International Journal of Procurement Management, 1 (3): 297-317.

Barney, Jay (1991): Firm Resources and Sustained Competitive Advantage, Journal of Management, 17 (1): 99-120.

Belmonte, Robert M. (1972): Another Look at Large-Scale Intergovernmental Cooperative Purchasing, Journal of Purchasing, 8 (1): 34-49.

Bernardes, Ednilson S. and George A. Zsidisin (2008): An Examination of Strategic Supply Management Benefits and Performance Implications, Journal of Purchasing and Supply Management, 14 (4): 209-219.

Blau, Peter M. (1970): A Formal Theory of Differentiation in Organizations, American Sociological Review, 35 (2): 201-218.

Blau, Peter M. (1972): Interdependence and Hierarchy in Organizations, Social Science Research, 1 (1): 1-24.

Bloom, Harold and James M. Nardone (1984): Organizational Level of the Purchasing Function, Journal of Purchasing and Materials Management, 20 (2): 14-17.

Call, Rex V. (1968): Purchasing in the Academic Institution, Journal of Purchasing, 4 (2): 70-77. 
Cavinato, Joseph L. (1992): Evolving Procurement Organizations: Logistics Implications, Journal of Business Logistics, 13 (1): 2745 .

Carduck, Christian (2000): International Procurement Offices: Internal Service Providers in Procurement Organizations of Multinational Corporations, Lang: Frankfurt/Main.

Carr, Amelia S. and John N. Pearson (2002): The Impact of Purchasing and Supplier Involvement on Strategic Purchasing and its Impact on Firm's Performance, International Journal of Operations and Production Management, 22 (9-10): 1032-1053.

Carr, Amelia S. and Larry R. Smeltzer (1997): An Empirically Based Operational Definition of Strategic Purchasing, European Journal of Purchasing and Supply Management, 3 (4): 199-207.

Carr, Amelia S. and Larry R. Smeltzer (1999): The Relationship Among Purchasing Benchmarking, Strategic Purchasing, Firm Performance, and Firm Size, Journal of Supply Chain Management, 35 (4): 51-60.

Chao, Chiang-Nan, Eberhard E. Scheuing, and William A. Ruch (1993): Purchasing Performance Evaluation: An Investigation of Different Perspectives, International Journal of Purchasing and Materials Management, 29 (3): 32-39.

Chen, Injazz J., Antony Paulraj, Augustine A. Lado (2004): Strategic Purchasing, Supply Management, and Firm Performance, Journal of Operations Management, 22 (5): 505-523.

Child, John (1970): More Myths of Management Organization?, Journal of Management Studies, 7 (3): 376-390.

Child, John (1972): Organizational Structure, Environment and Performance: The Role of Strategic Choice, Sociology, 6 (1): 1-22.

Child, John (1975): Managerial and Organizational Factors Associated With Company Performance - Part II. A Contingency Analysis, Journal of Management Studies, 12 (1): 12-27.

Child, John and Roger Mansfield (1972): Technology, Size, and Organization Structure, Sociology, 6 (3): 369-393.

Cooper, Harris M. (2010): Research synthesis and MetaAnalysis: A Step-by-Step Approach, 4th ed., Sage: Los Angeles et al.

Corey, E. Raymond (1978): Should Companies Centralize Procurement?, Harvard Business Review, 56 (6): 102-110.

Crozier, Michel and Jean-Claude Thoenig (1976): The Regulation of Complex Organized Systems, Administrative Science Quarterly, 21 (4): 547-570.

Crow, Lowell E. and Jay D. Lindquist (1985): Impact of Organizational and Buyer Characteristics on the Buying Center, Industrial Marketing Management, 14 (1): 49-58.

Daft, Richard L. (1992): Organization Theory and Design, $4^{\text {th }}$ ed., West Publishing: St. Paul et al..

David, Julie Smith., Yuhchang Hwang, Buck K. W. Pei, and J. Hal Reneau (2002): Performance Effects of Congruence Between Product Competitive Strategies and Purchasing Management Design, Management Science, 48 (7): 866-885.

David, Robert J. and Shin-Kap Han (2004): A Systematic Assessment of the Empirical Support for Transaction Cost Economics, Strategic Management Journal, 25 (1): 39-58.

Dawes, Philip L., Grahame R. Dowling, and Paul G. Patterson (1992): Factors Affecting the Structure of Buying Centers for the
Purchase of Professional Advisory Services, International Journal of Research in Marketing, 9 (3): 269-279.

Donaldson, Lex (1987): Strategy and Structural Adjustment to Regain Fit and Performance in Defence of Contingency Theory, Journal of Management Studies, 24 (1): 1-24.

Donaldson, Lex (2001): The contingency theory of organizations, Sage: Thousand Oaks et al.

Doucette, William R. (1997): Influences on Member Commitment to Group Purchasing Organizations, Journal of Business Research, 40 (3): 183-189.

Dubois, Frank L. and David Reeb (2000): Ranking the International Business Journals, Journal of International Business Studies, 31 (4): 689-704.

Eisenhardt, Kathleen M. (1989): Building Theories from Case Study Research, Academy of Management Review, 14 (4): 532550 .

Ellram, Lisa M. and Amelia S. Carr (1994): Strategic Purchasing: A History and Review of the Literature, International Journal of Purchasing and Materials Management, 30 (2): 9-18.

Ellram, Lisa M. and John N. Pearson (1993): The Role of the Purchasing Function: Toward Team Participation, International Journal of Purchasing and Materials Management, 29 (3): 2-9.

Englyst, Linda, Frances Jorgensen, John Johansen, and Ole S. Mikkelsen (2008): Commodity Team Motivation and Performance, Journal of Purchasing and Supply Management, 14 (1): 15-27.

Essig, Michael (2000): Purchasing Consortia as Symbiotic Relationships: Developing the Concept of "Consortium Sourcing", European Journal of Purchasing and Supply Management, 6 (1): 13-22.

Farrer, Dean G. (1969): The Organization of a Military Procurement Function, Journal of Purchasing, 5 (1): 68-81.

Fearon, Harold E. (1988): Organizational Relationships in Purchasing, Journal of Purchasing and Materials Management, 24 (4): 2-12.

Fearon, Harold E. and Donald L. Ayres (1967): Effect Of Centralized Purchasing On Hospital Costs, Journal of Purchasing, 3 (3): 22-35.

Ford, Jeffrey D. and John W. Slocum (1977): Size, Technology, Environment and the Structure of Organizations, Academy of Management Review, 2 (4): 561-575.

Galbraith, Jay R. (1971): Matrix Organization Designs, Business Horizons, 14 (1): 29-40.

Garrido-Samaniego, M. José and Jesús Gutiérrez-Cillán (2004): Determinants of Influence and Participation in the Buying Center: An Analysis of Spanish Industrial Companies, Journal of Business and Industrial Marketing, 19 (5): 320-336.

Gelderman, Cees J. and Janjaap Semeijn (2006): Managing the Global Supply Base Through Purchasing Portfolio Management, Journal of Purchasing and Supply Management, 12 (4): 209-217.

Germain, Richard and Cornelia Dröge (1997): Effects of Just-inTime Purchasing Relationships on Organizational Design, Purchasing Department Configuration, and Firm Performance, Industrial Marketing Management, 26 (2): 115-125.

Germain, Richard and Cornelia Dröge (1998): The Context, Organizational Design, and Performance of JIT Buying Versus Non- 
JIT Buying Firms, International Journal of Purchasing and Materials Management, 34 (2): 12-18.

Gianakis, Gerasimos A. and Xiao Hu Wang (2000): Decentralization of the Purchasing Function in Municipal Government: A National Survey, Journal of Public Budgeting, Accounting and Financial Management, 12 (3): 421-440.

Giunipero, Larry C. and Robert M. Monczka (1990): Organizational Approaches to Managing International Sourcing, International Journal of Physical Distribution and Logistics Management, 20 (4): 3-12.

Giunipero, Larry C. and Robert M. Monczka (1997): Organizational Approaches to Managing International Sourcing, International Journal of Physical Distribution and Logistics Management, 27 (5/6): 321-336.

Glock, Christoph H. and Ronald W. Bogaschewsky (2009): An Efficiency-Based Framework for Determining Organizational Costs in Purchasing, Conference Paper, http//www.ipsera.com/ assets/documents/wiesbpart2/pdf (Access date: 2011-11-18).

Glock, Christoph H. and Michael G. Broens (2011): The Organization of Purchasing at German Universities: An Empirical Investigation, International Journal of Public Administration, 34 (10), 662-673.

Goh, Mark and Geok-Theng Lau (1998): Electronics International Procurement Offices in Singapore, European Journal of Purchasing and Supply Management, 4 (2/3): 119-126.

Grønhaug, Kjell (1975): Autonomous vs. Joint Decisions in Organizational Buying, Industrial Marketing Management, 4 (5): 265271.

Grønhaug, Kjell (1976): Exploring Environmental Influences in Organizational Buying, Journal of Marketing Research, 13 (3): 225-229.

Hall, Richard H., J. Eugene Haas and Norman J. Johnson (1967): Organizational Size, Complexity, and Formalization, American Sociological Review, 32 (6): 903-912.

Hardwick, Clyde T. (1969): Regional Purchasing: A Study in Governmental Cooperative Buying, Journal of Purchasing, 5 (4): 13-19.

Hartmann, Evi, Gerhard Trautmann, and Christopher Jahns (2008): Organizational Design Implications of Global Sourcing: A Multiple Case Study Analysis on the Application of Control Mechanisms, Journal of Purchasing and Supply Management, 14 (1): 28-42.

Hickson, David J. (1966): A Convergence in Organization Theory, Administrative Science Quarterly, 11 (2): 224-237.

Hickson, David J., D. S. Pugh, and Diana C. Pheysey (1969): Operations Technology and Organization Structure: An Empirical Reappraisal, Administrative Science Quarterly, 14 (3): 378-397.

Holsti, Ole R. (1969): Content Analysis for the Social Sciences and Humanities, Addison-Wesley: Reading, MA.

Hult, G. Tomas M., William Neese, and Edward R. Bashaw (1997): Faculty Perceptions of Marketing Journals, Journal of Marketing Education, 19 (1): 37-52.

Inkson, J. H. K., D. S. Pugh and D. J. Hickson (1970): Organization Context and Structure: An Abbreviated Replication, Administrative Science Quarterly, 15 (3): 318-329.

Jennergren, L. Peter (1981): Decentralization in organizations, in Paul C. Nystrom and William H. Starbuck (eds.): Handbook of
Organizational Design, Vol. 2, Oxford University Press: Oxford, 39-59.

Johnson, P. Fraser (1999): The Pattern of Evolution in Public Sector Purchasing Consortia, International Journal of Logistics: Research and Applications, 2 (1): 57-73.

Johnson, P. Fraser, Robert D. Klassen, Michiel R. Leenders, and Harold E. Fearon (2002): Determinants of Purchasing Team Usage in the Supply Chain, Journal of Operations Management, 20 (1): $77-89$.

Johnson, P. Fraser and Michiel R. Leenders (2001): The Supply Organizational Structure Dilemma, Journal of Supply Chain Management, 37 (3): 4-11.

Johnson, P. Fraser and Michiel R. Leenders (2004): Implementing Organizational Change in Supply Towards Decentralization, Journal of Purchasing and Supply Management, 10 (4/5): 191200.

Johnson, Fraser P. and Michiel R. Leenders (2006): A Longitudinal Study of Supply Organizational Change, Journal of Purchasing and Supply Management, 12 (6): 332-342.

Johnson, P. Fraser, Michiel R. Leenders, and Harold E. Fearon (1998a): Evolving Roles and Responsibilities of Purchasing Organizations, International Journal of Purchasing and Materials Management, 34 (1): 2-11.

Johnson, P. Fraser, Michiel R. Leenders, and Harold E. Fearon (1998b): The Influence of Organizational Factors on Purchasing Activities, International Journal of Purchasing and Materials Management, 34 (3): 10-19.

Johnson, P. Fraser, Michiel R. Leenders, and Harold E. Fearon (2006): Supply's Growing Status and Influence: A Sixteen-Year Perspective, Journal of Supply Chain Management, 42 (2): 3343.

Johnson, P. Fraser, Michiel R. Leenders, and Clifford P. McCue (2003): A Comparison of Purchasing's Organizational Roles and Responsibilities in the Public and Private Sector, Journal of Public Procurement, 3 (1): 57-74.

Johnston, Wesley J. and Thomas V. Bonoma (1981a): The Buying Center: Structure and Interaction Patterns, Journal of Marketing, 45 (3): 143-156.

Johnston, Wesley J. and Thomas V. Bonoma (1981b): Purchase Process for Capital Equipment and Services, Industrial Marketing Management, 10 (4): 253-264.

Jones, Gareth R. (1998): Organizational Theory: Text and Cases, $2^{\text {nd }}$ ed., Addison-Wesley: Reading, MA.

Juha, Munnuka and Järvi Pentti (2008): Managing Risks in Organizational Purchasing Through Adaptation of Buying Centre Structure and the Buying Process, Journal of Purchasing and Supply Management, 14 (4): 253-262.

Kamann, Dirk-Jan F. (2007): Organizational Design in Public Procurement: A Stakeholder Approach, Journal of Purchasing and Supply Management, 13 (2): 127-136.

Ketchen, David J., James B. Thomas and Charles C. Snow (1993): Organizational Configurations] and Performance: A Comparison of Theoretical Approaches, Academy of Management Journal, 36 (6): $1278-1313$

Klebba, Joanne M. and F. Robert Dwyer (1981): Environmental Impact on Purchase Decision Structure, Journal of Purchasing and Materials Management, 17 (1): 30-36. 
Kolchin, Michael G. (1986) The Role of Structure in the Performance of Department Store Purchasing Agents, Journal of Purchasing and Materials Management, 22 (1): 7-12.

Kotteaku, Adrianna G., Lambros G. Laios, and Socrates J. Moschuris (1995): The Influence of Product Complexity on the Purchasing Structure, Omega, 23 (1): 27-39.

Laing, Angus W., Seonaidh Cotton, Rita Joshi, Gordon Marnoch, Lorna McKee and John Reid (1998): The Buying Centre: Patterns of Structure and Interaction in Primary Health Care, Service Industries Journal, 18 (3): 20-37.

Laing, Angus W. and Seonaidh Cotton (1997): Patterns of InterOrganizational Purchasing: Evolution of Consortia-Based Purchasing Amongst GP Fundholders, European Journal of Purchasing and Supply Management, 3 (2): 83-91.

Laois, Lambros and Evangelos Xideas (1994a): An Empirical Investigation of Institutional and Industrial Purchasing Structure, European Journal of Marketing, 28 (4): 20-38.

Laois, Lambros and Evangelos Xideas (1994b): An Investigation into the Structure of the Purchasing Function of State-Controlled Enterprises, Journal of Business Research, 29 (1): 13-21.

Lau, Geok-Theng., Mark Goh, and Shan Lei Phua (1999): Purchase-Related Factors and Buying Center Structure: An Empirical Assessment, Industrial Marketing Management, 28 (6): 573-587.

Lawrence, Paul R. and Jay W. Lorsch (1967): Organization and Environment: Managing Differentiation and Integration, Harvard University: Boston.

Lewin, Jeffrey E. (2001): The Effects of Downsizing on Organizational Buying Behavior: An Empirical Investigation, Journal of the Academy of Marketing Science, 29 (2): 151-164.

Lewin, Jeffrey E. and Naveen Donthu (2005): The Influence of Purchase Situation on Buying Center Structure and Involvement: A Selected Meta-Analysis of Organizational Buying Behavior Research, Journal of Business Research, 58 (10): 1381-1390.

Light, Richard J. and David B. Pillemer (1984): Summing Up: The Science of Reviewing Research, Harvard University Press: Cambridge, MA.

Lynn, Susan A. (1987): Identifying Buying Influences for a Professional Service: Implications for Marketing Efforts, Industrial Marketing Management, 16 (2): 119-130.

March, James G. and Sutton, Robert I. (1999): Organizational Performance as a Dependent Variable, in: James G. March (ed.): The Pursuit of Organizational Intelligence, Blackwell: Oxford et al., 338-354.

Mattson, Melvin R. (1988): How to Determine the Composition and Influence of a Buying Center, Industrial Marketing Management, 17 (3): 205-214.

McCabe, Donald L. (1987): Buying Group Structure: Constriction at the Top, Journal of Marketing, 51 (4): 89-98.

McCue, Clifford P. and Jack T. Pitzer (2000): Centralised vs. Decentralised Purchasing: Current Trends in Governmental Procurement Practices, Journal of Public Budgeting, Accounting \& Financial Management, 12 (3): 400-421.

McQuiston, Daniel H. (1989): Novelty, Complexity, and Importance as Causal Determinants of Industrial Buyer Behavior, Journal of Marketing, 53 (2): 66-79.
McWilliams, Robert D., Earl Naumann, and Stan Scott (1992): Determining Buying Center Size, Industrial Marketing Management, 21 (1): 43-49.

Meyer, Alan D., Anne S. Tsui and C. R. Hinings (1993): Configurational Approaches to Organizational Analysis, Academy of Management Journal, 36 (6): 1175-1195.

Milgrom, Paul R. and John Roberts (1992): Economics, Organization \& Management, Prentice Hall: New Jersey et al.

Mintzberg, Henry (1979): The Structuring of Organizations, Prentice Hall: New Jersey et al.

Mintzberg, Henry (1980): Structure in 5's: A Synthesis of the Research on Organization Design, Management Science, 26 (3): 322-341.

Mintzberg, Henry (1981): Organization Design: Fashion or Fit?, Harvard Business Review, 59 (1): 103-116.

Mintzberg, Henry (1991): The Effective Organization: Forces and Forms, Sloan Management Review, 32 (2): 54-67.

Mol, Michael J. (2003): Purchasing's Strategic Relevance, Journal of Purchasing \& Supply Management, 9 (1): 43-50.

Monczka, Robert M., Robert J. Trent, and Robert B. Handfield (2002): Purchasing and Supply Chain Management, $2^{\text {nd }}$ ed., South Western: Cincinnati, OH.

Naumann, Earl and John C. Kim (1986): A Macro Contingency Approach to the Study of Purchasing Behavior, Journal of Purchasing and Materials Management, 22 (3): 21-27.

Narasimhan, Ram and Joseph R. Carter (1990): Organisation, Communication and Coordination of International Sourcing, International Marketing Review, 7 (2): 6-20.

Nassimbeni, G. and M. Sartor (2006): International Purchasing Offices in China, Production Planning and Control, 17 (5): 494507.

Nellore, Rajesh and Jaideep Motwani (1999): Procurement Commodity Structures: Issues, Lessons and Contributions, European Journal of Purchasing and Supply Management, 5 (3/4): 157-166.

Newbert, Scott L. (2007): Empirical Research on the ResourceBased View of the Firm: An Assessment and Suggestions for Future Research, Strategic Management Journal, 28 (2): 121146.

Nollet, Jean and Martin Beaulieu (2003): The Development of Group Purchasing: An Empirical Study in the Healthcare Sector, Journal of Purchasing and Supply Management, 9 (1): 3-10.

Nollet, Jean and Martin Beaulieu (2005): Should an Organisation Join a Purchasing Group?, Supply Chain Management, 10 (1): 1117 .

Nollet, Jean, Silvia Ponce, and Manon Campbell (2005): About "Strategy" and "Strategies" in Supply Management, Journal of Purchasing and Supply Management, 11 (2/3): 129-140.

Pagano, Alessandro (2009): The Role of Relational Capabilities in the Organization of International Sourcing Activities: A Literature Review, Industrial Marketing Management, 38 (8): 903-913.

Pearson, John N. (1999): A Longitudinal Study of the Role of the Purchasing Function: Toward Team Participation, European Journal of Purchasing and Supply Management, 5 (2): 67-74. 
Peng, Mike W. (2001): The Resource-Based View and International Business, Journal of Management, 27 (6): 803-829.

Picot, Arnold, Helmut Dietl and Egon Franck (2002): Organisation, $3^{\text {rd }}$ ed., Schäffer-Poeschel: Stuttgart.

Pooley, John and Steven C. Dunn (1994): A Longitudinal Study of Purchasing Positions: 1960-1989, Journal of Business Logistics, 15 (1): 193-214.

Price, James L. (1972): Handbook of Organizational Measurement, Heath: Lexington, MA.

Pugh, D. S., D. J. Hickson, C. R. Hinings, K. M. Macdonald, C. Turner and T. Lupton (1963): A Conceptual Scheme for Organizational Analysis, Administrative Science Quarterly, 8 (3): 289-315.

Pugh, D. S., D. J. Hickson, C. R. Hinings, and C. Turner (1968): Dimensions of Organization Structure, Administrative Science Quarterly, 13 (1): 65-105.

Quintens, Lieven, Paul Matthyssens, and Wouter Faes (2005): Purchasing Internationalisation on Both Sides of the Atlantic, Journal of Purchasing and Supply Management, 11 (2/3): 57-71.

Quintens, Lieven, Pieter Pauwels, and Paul Matthyssens (2006a): Global Purchasing: State of the Art and Research Directions, Journal of Purchasing and Supply Management, 12 (4): 170-181.

Quintens, Lieven, Pieter Pauwels, and Paul Matthyssens (2006b): Global Purchasing Strategy: Conceptualization and Measurement, Industrial Marketing Management, 35 (7): 881-891.

Ramsay, John (2001): Purchasing's Strategic Irrelevance, European Journal of Purchasing and Supply Management, 7 (4): 257263.

Reck, Ross R. and Brian G. Long (1983): Organizing Purchasing as a Profit Center, Journal of Purchasing and Materials Management, 19 (4): 2-6.

Reynolds, Nina, Antonis Simintiras, and Efi Vlachou (2003): International Business Negotiations: Present Knowledge and Direction for Future Research, International Marketing Review, 20 (3): $236-261$.

Robbins, Stephen P. (1990): Organization Theory: Structure, Design and Applications, $3^{\text {rd }}$ ed., Prentice Hall: New Jersey et al.

Robinson, Patrick J., Charles W. Faris, and Yoram Wind (1967): Industrial Buying and Creative Marketing, Allyn and Bacon: Boston, MA.

Ruekert, Robert W., Orville C. Walker, and Kenneth J. Roering (1985): The Organization of Marketing Activities: A Contingency Theory of Structure and Performance, Journal of Marketing, 49 (1): $13-25$.

Sanchez-Rodriguez, C., D. Hemsworth, A. R. Martınez-Lorente and S. G. Clavel (2006): An Empirical Study on the Impact of Standardization of Materials and Purchasing Procedures on Purchasing and Business Performance, Supply Chain Management: 11 (1): 56-64.

Schiele, Joseph J. (2005): Improving Organizational Effectiveness Through Meaningful Involvement of Municipal Purchasing Departments: Case studies from Ontario Canada, Journal of Public Procurement, 5 (2): 145-163.

Schotanus, Fredo and Jan Telgen (2007): Developing a Typology of Organisational Forms of Cooperative Purchasing, Journal of Purchasing and Supply Management, 13 (1): 53-68.
Spekman, Robert E. and Louis W. Stern (1979): Environmental Uncertainty and Buying Group Structure: An Empirical Investigation, Journal of Marketing, 43 (2): 54-64.

Stanley, Linda L. (1993): Linking Purchasing Department Structure and Performance: Toward a Contingency Model, Journal of Strategic Marketing, 1 (3): 211-219.

Steinhauer, Raleigh F. (1972): IGCP: The Wave of the Future?, Journal of Purchasing, 8 (3): 34-45.

Steinhauer, Raleigh F. (1976): Intergovernmental Cooperative Purchasing, Journal of Purchasing and Materials Management, 12 (1): 29-33.

Telgen, Jan, Christine Harland, and Louise Knight (2007): Public Procurement in Perspective, in: Louise Knight, Christine Harland, Jan Telgen, Khi Y. Thai, Guy Callender, and Katy McKen (ed.): Public Procurement: International Cases and Commentary, Routledge: London et al., 16-24.

Tella, Eija and Velli-Matti Virolainen (2005): Motives Behind Purchasing Consortia, International Journal of Production Economics, 93-94 (1): 161-168.

Thomas, Gloria P. and John F. Grashof (1982): Impact of Internal and External Environmental Stability on the Existence of Determinant Buying Rules, Journal of Business Research, 10 (2): 159168.

Tirimanne, D. N. and A. Ariyawardana (2008): Use of Organizational Design Features in Purchasing, Journal of Management Research, 8 (3): 162-167.

Trautmann, Gerhard, Lydia Bals, and Evi Hartmann (2009): Global Sourcing in Integrated Network Structures: The Case of Hybrid Purchasing Organizations, Journal of International Management, 15 (2): 194-208.

Trautmann, Gerhard, Virpi Turkulainen, Evi Hartmann, and Lydia Bals (2009): Integration in the Global Sourcing Organization: An Information Processing Perspective, Journal of Supply Chain Management, 45 (2): 57-74.

Trent, Robert J. (1996): Understanding and Evaluating CrossFunctional Sourcing Team Leadership, International Journal of Purchasing and Materials Management, 32 (4): 29-36.

Trent, Robert J. (1998): Individual and Collective Team Effort: A Vital Part of Sourcing Team Success, International Journal of Purchasing and Materials Management, 34 (4): 46-54.

Trent, Robert J. (2004): The Use of Organizational Design Features in Purchasing and Supply Management, Journal of Supply Chain Management, 40 (3): 4-18.

Trent, Robert J. and Robert M. Monczka (1994): Effective CrossFunctional Sourcing Teams: Critical Success Factors, International Journal of Purchasing and Materials Management, 30 (4): 3-11.

Trent, Robert J. and Robert M. Monczka (2003): International Purchasing and Global Sourcing: What Are the Differences?, Journal of Supply Chain Management, 39 (4): 26-37.

Walker, Helen (2009): Sustainable Procurement: A Literature Review, Conference Paper, http//www.ipsera.com/assets/docu ments/wiesbpart2/pdf (Access date: 2011-11-18).

Webster, Frederick E. and Yoram Wind (1972): A General Model for Understanding Organizational Buying Behavior, Journal of Marketing, 36 (2): 12-19. 
Williamson, Oliver E. (1981): The Economics of Organization: The Transaction Cost Approach, American Journal of Sociology, 87 (3): 548-577.

Wood, John (2005): Organizational Configuration as an Antecedent to Buying Centers' Size and Structure, Journal of Business and Industrial Marketing, 20 (6): 263-275.

Xideas, Evangelos and Socrates J. Moschuris (1998): The Influence of Product Type on the Purchasing Structure, European Journal of Marketing, 32 (11/12): 974-992.

Yin, Robert K. (2009): Case Study Research: Design and Methods, $4^{\text {th }}$ ed., Sage: Los Angeles.

Zey-Ferrell, Mary (1981): Criticisms of the dominant perspective on organization, The Sociological Quarterly, 22 (2): 181-205.

Zheng, Jurong, Louise Knight, Christine Harland, Stuart Humby, and Ken James (2007): An Analysis of Rresearch Into the Future of Purchasing and Supply Management, Journal of Purchasing and Supply Management, 13 (1): 69-83.

\section{Biographies}

Christoph H. Glock is an Assistant Professor of Industrial Management at the University of Würzburg. His research interests include inventory management, supply chain coordination, supply chain organization and supplier selection. Dr. Glock has been published in renowned international journals, such as the International Journal of Production Economics, the International Journal of Production Research, Computers \& Industrial Engineering or the Zeitschrift für Betriebswirtschaft.

Simon Hochrein studied Business Administration (Industrial Management and Human Resource Management) and works now as a research assistant at the Department of Industrial Management at the University of Würzburg. His research interests include strategic supply management, organizational issues in purchasing, supply controlling and performance management as well as incentive and compensation systems in supply. He also serves as a referee for renowned international journals, such as the International Journal of Production Research, the Journal of Operations Management and the Computers \& Industrial Engineering. 